\title{
Family firm internationalization: Past research and an agenda for the future
}

\author{
Jean-Luc Arregle ${ }^{1}$, \\ Francesco Chirico ${ }^{2,3}$, \\ Liena Kano ${ }^{4}$, Sumit K. Kundu ${ }^{5}$, \\ Antonio Majocchi ${ }^{6}$ and \\ William S. Schulze ${ }^{7}$

\begin{abstract}
${ }^{1}$ EM Lyon Business School, Écully, France;
${ }^{2}$ Macquarie Business School, Macquarie University, North Ryde, Australia; ${ }^{3}$ Centre for Family Entrepreneurship and Ownership (CeFEO), Jonkoping International Business School, Jonkoping University, Jönköping, Sweden; ${ }^{4}$ Haskayne School of Business, University of Calgary, Calgary, Canada; ${ }^{5}$ Department of International Business, College of Business, Florida International University, Miami, USA;

${ }^{6}$ Dipartimento di impresa e management, Luiss Guido Carli, Rome, Italy; ${ }^{7}$ David Eccles School of Business, University of Utah, Salt Lake City, USA
\end{abstract} \\ Correspondence: \\ J.L. Arregle, EM Lyon Business School, Écully, \\ France \\ e-mail: arregle@em-lyon.com
}

\begin{abstract}
Although the study of family firm internationalization has generated considerable scholarly attention, existing research has offered varied and at times incompatible findings on how family ownership and management shape internationalization. To improve our understanding of family firm internationalization, we systematically review 220 conceptual and empirical studies published over the past three decades, structuring our comprehensive overview of this field according to seven core international business (IB) themes. We assess the literature and propose directions for future research by developing an integrative framework of family firm internationalization that links IB theory with conceptual perspectives used in the reviewed body of work. We propose a research agenda that advocates a cross-disciplinary, multitheoretic, and cross-level approach to studying family firm internationalization. We conclude that family firm internationalization research has the potential to contribute valuable insights to IB scholarship by increasing attention to conceptual and methodological issues, including micro-level affective motivations, background social institutions, temporal perspectives, and multilevel analyses.
\end{abstract}

Journal of International Business Studies (2021) 52, II59-| 198.

https://doi.org/ 10.1057/s41267-021-00425-2

Keywords: systematic review; family firm internationalization; international business theory

The online version of this article is available Open Access

\section{INTRODUCTION}

Family firms dominate the business landscape. They employ about $60 \%$ of the global workforce and generate over half of the world's gross domestic product (GDP) (Family Firm Institute, 2017). Yet, family firms are not only important domestic producers: they are also prominent in international business (IB). The Economist (2015) predicts that the share of large multinational businesses owned or controlled by families will increase from about $15 \%$ to $40 \%$ by 2025. This trend is evident in Europe, where family companies like Ferrero and Michelin are important international players; in North America, with such companies as Walmart and Johnson \& Johnson; in Australia, with Hancock Prospecting and Visy Industries; and in Asia, where examples include Hutchison Whampoa of Hong Kong, the Salim Group of Indonesia, and the Tata Group of India.
Supplementary Information The online version contains supplementary material available at https://doi.org/10.1057/s41267021-00425-2.

Received: 31 January 2020

Revised: 28 February 2021

Accepted: 4 March 2021

Online publication date: 14 June 2021 
Although the prominence of family enterprise in the world economy has captured the interests of scholars across a variety of disciplines, IB scholars have been slow to embrace family business internationalization as a research field. In recent years, a broad consensus has emerged that family firms' singular governance features shape their internationalization behavior. This potential uniqueness of family business internationalization has driven increased scholarly activity in this realm (Alayo, Iturralde, Maseda, \& Aparicio, 2020; Debellis, Rondi, Plakoyiannaki, \& De Massis, 2020b). Yet, IB scholars focus on traditional IB topics and assume that the influence of the controlling family on firm conduct is relatively homogeneous (Pukall \& Calabrò, 2014). Meanwhile, family business scholars focus on family-driven phenomena and rarely explore questions motivated by IB theory. Moreover, existing research is highly heterogeneous, characterized by varied and often contrasting conceptual perspectives and definitions, and by diverse and incompatible measures (Arregle, Duran, Hitt, \& van Essen, 2017). As a result, scholars struggle to access relevant research about how family ownership and management shape internationalization.

Extant reviews of family firms' internationalization predominantly address the family business audience (e.g., Alayo et al., 2020; Casillas \& Moreno-Menéndez, 2017; Kontinen \& Ojala, 2010; Pukall \& Calabrò, 2014), explore the evolution of the family firm internationalization literature (Debellis, De Massis, Petruzzelli, Frattini, \& Del Giudice, 2020a), or focus on specific facets of family firm internationalization such as the internationalization process (e.g., Metsola, Leppäaho, Paavilainen-Mäntymäki, \& Plakoyiannaki, 2020) and family SME internationalization (e.g., Lahiri, Mukherjee, \& Peng, 2020). None specifically addresses the broad disciplinary needs of the IB audience. ${ }^{1}$ To accomplish this task, we offer a comprehensive review and assessment of the emerging field of international family business from an IB perspective. We review 220 conceptual and empirical articles on family business internationalization published in international academic journals through 2020. We organize and present these studies using IB themes - elements of international strategy that are common to most IB frameworks, and related to decisions about "the what, the where, and the how of internationalization" (Dunning \& Kundu, 1995: 101). Hence, this review is IB-oriented but phenomenon-driven, and summarizes and articulates the theories used to understand internationalization in the context of family firms. Context has been a key element of IB research (Buckley \& Lessard, 2005). In fact, attention to specific contexts (e.g., emerging/transition economies, see Buckley, Doh, \& Benischke, 2017; Hennart, 2012; Meyer \& Peng, 2016; historical context, see Verbeke \& Kano, 2015) has allowed researchers to refine and better understand the sensitivity of IB theories to their context. The family firm context has such potential.

After discussing our methodology in this review, we offer an overview of the family firm definitions employed in the reviewed studies. We then provide a comprehensive overview of the studies on family firm internationalization, organized according to seven key IB themes. We assess the literature, propose research opportunities, and discuss implications for both family firm internationalization and IB research as a whole. We believe that greater integration of IB concepts with the family firm internationalization literature, along with a stronger emphasis on the multilevel conceptual and empirical structure of family firm internationalization, will enrich the IB discipline while helping family firm scholars reconcile the many contradictions and conflicting perspectives found in this literature.

\section{METHODOLOGY}

Family firm internationalization is an emerging field of research, with contributions dispersed in multiple journals across different academic disciplines. Because the field is young and diverse, we chose to offer a systematic review of all relevant contributions (and not just those published in toptier academic journals), starting with the very first academic articles published about family firm internationalization (i.e., Donckels \& Fröhlich, 1991; Gallo \& Sveen, 1991). Accordingly, we surveyed all academic journals with relevant articles on the topics of internationalization and/or family firms (Hoskisson, Chirico, Zyung, \& Gambeta, 2017; Wan, Hoskisson, Short, \& Yiu, 2011) for the period 1991 to $2020 .^{2}$ We maintain that an inclusive approach is well suited for this emerging academic field, which, in its early years, lacked a constituency. Perhaps as a result of low interest, the topic was, at least initially, neglected by the top-tier journals, causing many early important contributions to find homes in less prestigious journals. ${ }^{3}$ 
We followed an established systematic review methodology, Preferred Reporting Items for Systematic Reviews and Meta-Analysis Protocols (or PRISMA-P) (Shamseer et al., 2014) to execute our study. Specific steps undertaken include: (1) identifying the scope of the review (temporal boundaries and sources); (2) selecting keywords and conducting literature search; (3) screening identified studies for inclusion in the review; (4) assessing and coding studies; and (5) synthetizing findings and writing up the analysis. We detail these steps below.

We conducted a systematic search (Tranfield, Denyer, \& Smart, 2003) using keywords related to family firms and internationalization on five major electronic databases, including both disciplinespecific (ABI/Inform database) and interdisciplinary databases (EBSCO database, Google Scholar, ISI Web of Knowledge, and Scopus). ${ }^{4}$ The initial search yielded 297 articles. Each identified paper was screened separately by at least two of the authors and an academic external to the authors' team to ensure that it met our criterion for relevance. We eliminated 77 articles that casually mentioned family business or internationalization or did not specifically explore family governance and/or dimensions of IB as dependent or independent variables. The resulting 220 articles are reported in Appendix 1. For each article, we report key information, including source, theoretical frame, methodology, sample, family firm definition, key variables, and findings. Consistent with our claim that this is an emergent field, the majority (65\%) of articles listed in Appendix 1 were published in the last 7 years.

We coded our 220 articles according to theories employed, research questions, and major topics of investigation. Then, we iteratively cross-referenced these articles with major IB-centric research questions related to the 'what, where, and how's' of internationalization (Dunning, 1993; Dunning \& Kundu, 1995). The iterative process yielded seven categories that play a central role in IB studies: (1) scale (or depth) of internationalization; (2) scope (or breadth) of internationalization; (3) international entry mode choice ${ }^{5}$; 4 ) international location choice; (5) internationalization process; (6) timing, or pace and rhythm of internationalization; and (7) internationalization performance. These seven categories, henceforth IB themes, encompass core phenomena addressed in the reviewed studies, but also represent key aspects of family firm internationalization decisions and outcomes (De
Massis, Frattini, Majocchi, \& Piscitello, 2018), as well as research themes that cut broadly across most IB frameworks (Verbeke, 2013).

We structured our review using these IB themes as our organizational frame. Three themes (scale, scope, and performance) represent outcomes of internationalization. The remaining four themes (entry mode, location choice, internationalization process, and timing) encompass the range of internationalization decisions and actions taken by family firms. Within each IB theme, we evaluate the extent to which scholarly consensus about the influence of family on internationalization exists, highlight theoretical contributions, and identify knowledge gaps and directions for future research. We also explore the host of methodological issues that have limited the development of theory about family firm internationalization and propose solutions. The results of this detailed analysis are presented in the following sections. We begin by discussing family firm definitions and their implications for family firm internationalization research.

\section{FAMILY FIRM DEFINITIONS}

Definitions of family firms differ widely across the literatures in family business (Chua, Chrisman, \& Sharma, 1999), management (Anderson \& Reeb, 2003; Schulze, Lubaktin, Dino, \& Buchholtz, 2001) and IB (Arregle et al., 2017; Hennart, Majocchi, \& Forlani, 2019). Many studies assert that family ownership is the defining proxy (e.g., Carr \& Bateman, 2009), whereas others suggest that family firms must have substantial levels of family ownership and involvement in firm management to satisfy the criterion (e.g., Alayo, Maseda, Iturralde, $\&$ Arzubiaga, 2019). Other studies differentiate between family-controlled firms (those over which families have unilateral control due to their level of ownership and managerial oversight) and familyinfluenced firms (over which family owners and managers have much less control) (Chua et al., 1999; Sirmon, Arregle, Hitt, \& Webb, 2008). Finally, some researchers contend that emotions, social relationships, and intergenerational succession that is, the family's intent to pass ownership of the business to the next generation - are the defining attributes of the family firm that should be integrated into family firm definitions (Salvato, Chirico, Melin, \& Seidl, 2019).

The definition of the family firm matters because it identifies characteristics that exert varying 
influence on internationalization. Characteristics like ownership and managerial involvement are influential, because family firms occupy a distinctive social and institutional position within the economy. The family, along with the Church, State, and educational system, is one of the fundamental social institutions (Calori, Lubatkin, Very, \& Veiga, 1997; Whitley, 1992). As such, the family imprints collective knowledge on individuals (Calori et al., 1997; Whitley, 1992) and exerts a mimetic and normative influence on family firm conduct (Arregle, Hitt, \& Mari, 2019). Thus, the family imposes a set of institutional constraints upon the family firm and its managers (Arregle et al., 2007). Moreover, historically, family firms have shaped the social, legal, political, and financial institutions that support them (Soleimanof, Rutherford, \& Webb, 2018). Institutional forces thus both constrain and enable family firm conduct, and influence different internationalization outcomes. As we will show, differing family firm definitions partially account for inconsistent and conflicting results. Accordingly, we indicate in Appendix 1 the definition of family firms used in each reviewed paper. Table 1 summarizes the main distinguishing characteristics of family firms, and their related meanings and effects on organizations, namely: 1) family influence or control; 2) emotional attachment and identification; 3) distinctive social capital; 4) transgenerational intent; and 5) generational involvement.

\section{LITERATURE REVIEW ON FAMILY FIRM INTERNATIONALIZATION}

In this section, we synthetize family firm internationalization studies that address each of seven core IB themes: (1) scale of family firm internationalization (39\% of studies); (2) scope of internationalization (8\%); (3) entry mode choice (18\%); (4) international location choice (3\%); (5) internationalization process $(16 \%)$; (6) pace and rhythm of internationalization (4\%); and (7) internationalization performance $(12 \%)^{6}$. We summarize core findings and identify conflicts and the sources of inconsistencies across studies in Table 2, and discuss as follows.

\section{Explaining Family Firms' International Scale}

The majority of extant research contends that unique features of family firms influence their international scale. However, there is no consensus about which of these features, alone or in tandem, facilitate or constrain internationalization (Arregle et al., 2017). For example, in a study of international orientation in the world's top family firms, Carr and Bateman (2009) conclude that family firms are more internationally oriented than nonfamily firms, whereas Gómez-Mejía, Makri, and Larraza Kintana (2010) reach the opposite conclusion. The effect of owner-management is a particularly contentious issue. For example, stewardship scholars (Davis, Schoorman, \& Donaldson, 1997) suggest that family owner-managers' strong identification with the firm, and their commitment to the long-run welfare of the firm and its employees, motivate them to act in the best interest of the firm, even when presented with challenges and risks. Stewardship thus helps explain the positive influence of family ownership and management on a family firm's international scale (James, 1999; Singh \& Gaur, 2013; Zahra, 2003). In contrast, agency theory scholars (e.g., Santulli, Torchia, Calabrò, \& Gallucci, 2019) argue that the many private benefits of owner-management give majority family owners incentive to prioritize control of their firms (Faccio, Lang, \& Young, 2001). Because the complexity of international operations often requires that firms delegate authority in ways that reduce control (Alessandri, Cerrato, \& Eddleston, 2018), family owners are less likely to internationalize. Van Essen, Carney, Gedajlovic, and Heugens (2015) also conclude that family firms are less internationally oriented, attributing this fact to agency conflicts between majority family shareholders, who are better positioned to reap the private benefits of control, and minority shareholders, who stand to benefit from internationalization and reduced family control. Singla, Veliyath, and George (2014) provide further evidence that these agency conflicts within family firms hinder international scale.

Similar contradictions emerge from studies of family managers' risk attitude. Gallo and Pont (1996) assume that the alignment of owner-manager interest in family firms reduces agency costs and promotes the firms' willingness to pursue risky activities such as developing international scale. However, scholars espousing a socio-emotional wealth (SEW) perspective argue that family owner-managers prioritize the preservation of family's SEW. SEW comprises "the nonfinancial aspects of the firm that meet the family's affective needs, such as identity, the ability to exercise family influence, and the perpetuation of the family dynasty" (Gómez-Mejía, Haynes, Núñez-Nickel, 
Table 1 Distinguishing characteristics of family firms

\begin{tabular}{|c|c|c|c|}
\hline $\begin{array}{l}\text { Distinguishing } \\
\text { characteristics of } \\
\text { family firms }\end{array}$ & Meanings/facts & Exemplary effects/outcomes & $\begin{array}{l}\text { Examples of references in family firm } \\
\text { literature }\end{array}$ \\
\hline $\begin{array}{l}\text { Family influence } \\
\text { or control }\end{array}$ & $\begin{array}{l}\text { A family coalition has a } \\
\text { significant presence in } \\
\text { ownership, or ownership and } \\
\text { management. }\end{array}$ & $\begin{array}{l}\text { - Family goals are prioritized. } \\
\text { - Stewardship behavior, agency costs, } \\
\text { altruism. } \\
\text { - Conflicts with non-family } \\
\text { stakeholders. } \\
\text { - Minority shareholders exploitation. } \\
\text { - Fast decision making. } \\
\text {... }\end{array}$ & $\begin{array}{l}\text { Anderson and Reeb (2003), Berrone } \\
\text { et al. (2012), Le Breton-Miller, Miller } \\
\text { \& Lester (2011), Salvato et al. } \\
\text { (2019), Schulze, Lubatkin, \& Dino } \\
\text { (2003). }\end{array}$ \\
\hline $\begin{array}{l}\text { Emotional } \\
\text { attachment and } \\
\text { identification }\end{array}$ & $\begin{array}{l}\text { Family members are strongly } \\
\text { emotionally attached and } \\
\text { identify with the family firm. }\end{array}$ & $\begin{array}{l}\text { - Family goals are prioritized. } \\
\text { - Departure from profit-maximizing } \\
\text { behavior. } \\
\text { - Stewardship behavior, agency costs, } \\
\text { altruism. } \\
\text { - Preserve the firm image/reputation. } \\
\text { - Survivability capital. } \\
\text {... }\end{array}$ & $\begin{array}{l}\text { Berrone et al. (2012), Miller and Le } \\
\text { Breton-Miller (2005), Salvato et al. } \\
\text { (2019), Sirmon and Hitt (2003), } \\
\text { Schulze et al. (2003). }\end{array}$ \\
\hline $\begin{array}{l}\text { Unique social } \\
\text { capital }\end{array}$ & $\begin{array}{l}\text { Family members enjoy strong } \\
\text { levels of internal and external } \\
\text { social capital. }\end{array}$ & $\begin{array}{l}\text { - Deep relationships, trust and shared } \\
\text { values or norms. } \\
\text { - Strong local embeddedness and } \\
\text { relational governance. } \\
\text { - Community citizenship. } \\
\text { - Amoral familism. } \\
\text { - Corporate social responsibility. } \\
\text {... }\end{array}$ & $\begin{array}{l}\text { Arregle et al. (2007), Berrone et al. } \\
\text { (2012), Bird and Wennberg (2014), } \\
\text { Miller and Le Breton-Miller (2005), } \\
\text { Sirmon and Hitt (2003). }\end{array}$ \\
\hline $\begin{array}{l}\text { Transgenerational } \\
\text { intention }\end{array}$ & $\begin{array}{l}\text { Family members intent to } \\
\text { transfer across generations (the } \\
\text { vision of) the business held by } \\
\text { the dominant family coalition. }\end{array}$ & $\begin{array}{l}\text { - Family goals are prioritized. } \\
\text { - Dynastic succession. } \\
\text { - Nepotism. } \\
\text { - Long term orientation, persistence } \\
\text { and resilience. } \\
\text { - Patient capital. } \\
\text {... }\end{array}$ & $\begin{array}{l}\text { Berrone et al. (2012), Chirico et al. } \\
\text { (2020), Salvato et al. (2019), Sirmon } \\
\text { and Hitt (2003), Zellweger and } \\
\text { Astrachan (2008). }\end{array}$ \\
\hline $\begin{array}{l}\text { Generational } \\
\text { involvement }\end{array}$ & $\begin{array}{l}\text { The family structure changes } \\
\text { through the passage of time. }\end{array}$ & $\begin{array}{l}\text { - Knowledge accumulation and } \\
\text { diversity. } \\
\text { - Goal (financial and non-financial) } \\
\text { divergence. } \\
\text { - Family conflicts. } \\
\text { - Entrepreneurial behavior. } \\
\ldots\end{array}$ & $\begin{array}{l}\text { Kellermanns and Eddleston (2004), } \\
\text { Kotlar and De Massis (2013), Salvato } \\
\text { et al. (2019), Sciascia, Mazzola, \& } \\
\text { Chirico, (2013). }\end{array}$ \\
\hline
\end{tabular}


Table 2 Explaining family firm internationalization: summary of core IB themes and main findings

\begin{tabular}{|c|c|c|c|}
\hline Core IB theme & Main findings/perspectives & Sources of contradiction & Comments \\
\hline International scale & 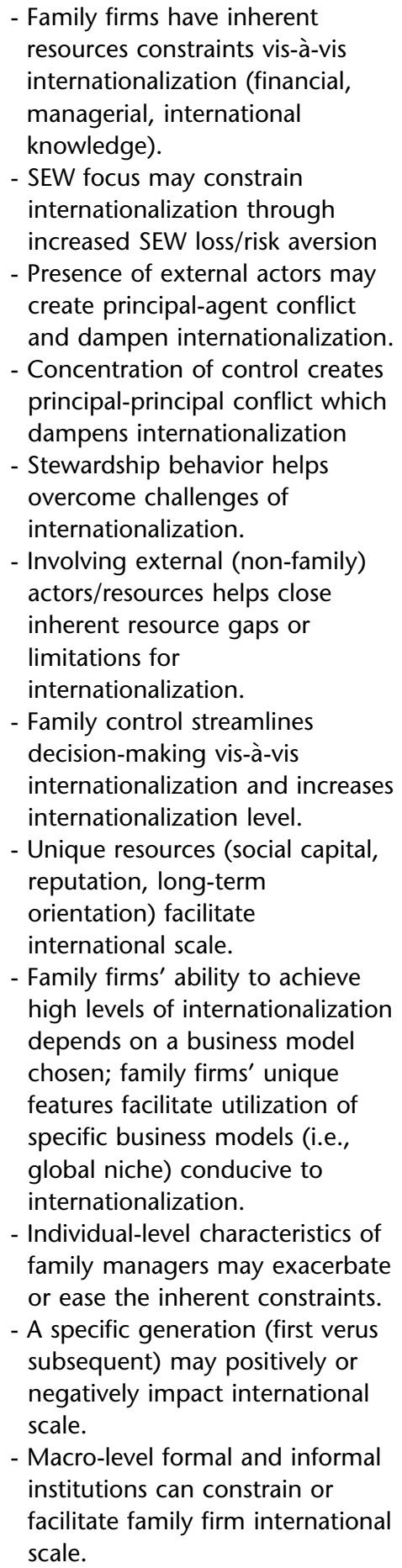 & $\begin{array}{l}\text { - Diverging theoretical starting } \\
\text { points and assumptions (e.g., } \\
\text { stewardship versus agency } \\
\text { theory). } \\
\text { - The same theory (e.g., social } \\
\text { capital, agency) can explain } \\
\text { positive or negative effects. } \\
\text { - Broad-base comparison of family } \\
\text { versus non-family firms' } \\
\text { international scale, with diverging } \\
\text { operationalizations of family firms } \\
\text { and measures of } \\
\text { internationalization. } \\
\text { - Samples may not be } \\
\text { representative (single-country } \\
\text { investigations yield diverging } \\
\text { results). } \\
\text { - Insufficient consideration of } \\
\text { family firm heterogeneity } \\
\text { - Insufficient consideration of the } \\
\text { different risk profiles of } \\
\text { internationalization. } \\
\text { - Narrow focus on isolated sources } \\
\text { of heterogeneity and their } \\
\text { influence on internationalization. } \\
\text { - Differences in internal and } \\
\text { external context at individual, } \\
\text { family, firm and macro levels } \\
\text { (e.g., a specific generation's } \\
\text { propensity to facilitate versus } \\
\text { constrain internationalization } \\
\text { depends on competencies and } \\
\text { education levels of the } \\
\text { generation; relationships in the } \\
\text { family etc.). }\end{array}$ & $\begin{array}{l}\text { Broad consensus exists that family } \\
\text { firms possess idiosyncratic features, } \\
\text { and that their resource reservoirs } \\
\text { are unique, impacting international } \\
\text { scale in a unique way. But extant } \\
\text { work diverges on whether these } \\
\text { unique features facilitate versus } \\
\text { constrain internationalization. The } \\
\text { contradiction is particularly } \\
\text { apparent in studies that attempt to } \\
\text { establish a generalized relationship } \\
\text { between family ownership- } \\
\text { management and } \\
\text { internationalization. } \\
\text { The main reason for contradicting } \\
\text { results is the general lack of } \\
\text { contextual considerations, and } \\
\text { insufficient incorporation of } \\
\text { heterogeneity (at all levels, i.e., } \\
\text { individual, family, firm, and macro) } \\
\text { into the exploration. Those studies } \\
\text { that explore heterogeneity typically } \\
\text { (although with some exceptions) } \\
\text { focus on a single source of } \\
\text { heterogeneity at a single level of } \\
\text { analysis (e.g., certain institutional } \\
\text { features at a macro level), and } \\
\text { therefore do not necessarily } \\
\text { reconcile the diverging results in a } \\
\text { broad sense. }\end{array}$ \\
\hline
\end{tabular}


Table 2 (Continued)

\begin{tabular}{|c|c|c|c|}
\hline Core IB theme & Main findings/perspectives & Sources of contradiction & Comments \\
\hline International scope & $\begin{array}{l}\text { - Family ownership has a positive } \\
\text { impact on international scope } \\
\text { due to owners' propensity toward } \\
\text { stewardship behavior } \\
\text { - Family management constrains } \\
\text { internationalization scope due to } \\
\text { risk aversion of owner-managers. } \\
\text { Increasing international scope } \\
\text { inflicts higher demands on } \\
\text { resources, requires greater } \\
\text { international experience on the } \\
\text { part of family members, and } \\
\text { increases SEW loss potential. } \\
\text { - Family managers' social capital is } \\
\text { locally/regionally bound and } \\
\text { lacks diversity, constraining } \\
\text { international scope. } \\
\text { - Strong family social capital } \\
\text { creates close ties between } \\
\text { generations. It sustains the } \\
\text { founder's imprint on firm }\end{array}$ & $\begin{array}{l}\text { - Different definitions of family } \\
\text { firms. } \\
\text { - Failure to differentiate between } \\
\text { family ownership, management, } \\
\text { influence, and control in some } \\
\text { studies. } \\
\text { - Lack of nuanced differentiation } \\
\text { within central constructs (e.g., } \\
\text { among different types of external } \\
\text { actors, different objectives for the } \\
\text { firm). }\end{array}$ & $\begin{array}{l}\text { In studies that focus specifically on } \\
\text { international scope, a greater } \\
\text { degree of consensus exists, with } \\
\text { the majority of studies suggesting } \\
\text { that international scope in family } \\
\text { firms is lower than in nonfamily } \\
\text { ones. } \\
\text { Diverging results regarding the } \\
\text { effect of external actors on } \\
\text { international scope can be } \\
\text { reconciled by differentiating } \\
\text { among different types of nonfamily } \\
\text { actors: external owners, board } \\
\text { members, and } \\
\text { employees/managers affect } \\
\text { international scope in different } \\
\text { ways; the specific impacts further } \\
\text { depend on contextual factors such } \\
\text { as governance systems, strategic } \\
\text { objectives, generational } \\
\text { characteristics, etc. }\end{array}$ \\
\hline
\end{tabular}

International entry modes strategy, limiting international scope changes and increases.

- Resources brought by external (i.e., non-family) owners, managers, and board members can mitigate the negative impacts of family governance on international scope.

- The type of family firm (familycontrolled or family-influenced) matters: Higher \% of external directors or managers have a negative effect on international scope in family-controlled firms, and a positive effect in familyinfluenced firms.

- High \% of family ownership discourages high commitment entry modes associated with risks of committing resources.

- Family firms tend to gradually switch from lower to higher commitment entry modes, e.g., from exporting to JV to WOS.

- Cooperative entry modes are often sought as a means of lowering risk and accessing host market knowledge.

- Family firms tend to seek out entry modes that grant them maximum control over operations.

- Family firms tend to prefer greenfield entry to acquisition
- Different theoretical starting point/assumptions (e.g., agency theory assumes full rationality; TCE assumes bounded rationality). - Inherent risk aversion often assumed without testing. - Risk aversion (even if confirmed) may lead to diverging entry strategies, for example, cooperative entry in order to close resource gaps versus WOS in order to safeguard against partner unreliability; specific strategies chosen depend on contextual factors.

- SEW is adopted as a blanket assumption, however, internationalization behavior
Many studies are characterized by assumption-omitted testing, whereby risk avoidance is assumed and used as a basis of hypotheses development, but is not necessarily tested or confirmed. Further, most of the differences in results regarding family firms' preferred foreign entry and operating modes are due to contextual characteristics that influence mode choices. Many studies explore these heterogeneous features at micro (e.g., biases, SEW preferences, individual's experience and capabilities), family (e.g., the presence or absence of intra-family conflict), firm (e.g., 
Table 2 (Continued)

\begin{tabular}{|c|c|c|c|}
\hline Core IB theme & Main findings/perspectives & Sources of contradiction & Comments \\
\hline & $\begin{array}{l}\text { - Acquisition may be preferable at } \\
\text { later stages of } \\
\text { internationalization, while JVs are } \\
\text { more likely upon initial entry. } \\
\text { - Entry mode choice is determined } \\
\text { by a number of contextual } \\
\text { factors, including level of foreign } \\
\text { experience, characteristics of } \\
\text { potential partners (ownership } \\
\text { structure), host country } \\
\text { characteristics (level of } \\
\text { environmental uncertainty, } \\
\text { distance), home and host country } \\
\text { institutions, individual } \\
\text { preferences and biases of owners } \\
\text { (SEW preferences, bifurcation } \\
\text { bias, risk tolerance), types of } \\
\text { assets transferred to host } \\
\text { countries, governance structure, } \\
\text { internationalization motives. } \\
\text { - Ownership structure (family } \\
\text { versus non-family) is not a } \\
\text { significant prediction of entry } \\
\text { mode choice. }\end{array}$ & $\begin{array}{l}\text { depends on what dimension of } \\
\text { SEW is prioritized/on specific } \\
\text { noneconomic goals. } \\
\text { - Contextual differences. } \\
\text { - Differences in sample } \\
\text { characteristics. }\end{array}$ & $\begin{array}{l}\text { international experience, } \\
\text { governance, ownership, resources, } \\
\text { motives) and macro (institutions, } \\
\text { various dimensions of distance, } \\
\text { stability/uncertainty) levels. It } \\
\text { seems that establishing a } \\
\text { generalized relationship between } \\
\text { family ownership-management } \\
\text { and preferred entry modes is a } \\
\text { futile task; rather, a more fruitful } \\
\text { way forward is to investigate } \\
\text { unique drivers of governance } \\
\text { decisions in family firms, as well as } \\
\text { contextual characteristics that } \\
\text { shape these decisions. }\end{array}$ \\
\hline $\begin{array}{l}\text { International } \\
\text { location choice }\end{array}$ & $\begin{array}{l}\text { - Higher levels of family ownership } \\
\text { are associated with higher-risk FDI } \\
\text { locations (risk aversion promotes } \\
\text { long-term strategy that increases } \\
\text { the probability of investment in } \\
\text { riskier markets). } \\
\text { - Family firms tend to favor } \\
\text { culturally proximate host } \\
\text { locations. } \\
\text { There is no de facto preference for } \\
\text { low distance locations. } \\
\text { - Market choices depend on micro- } \\
\text { level factors such as dominant risk } \\
\text { perceptions, presence/absence of } \\
\text { bifurcation bias, personal } \\
\text { preferences/objectives of owners. }\end{array}$ & $\begin{array}{l}\text { - Contextual differences. } \\
\text { - Differences in sample } \\
\text { characteristics. } \\
\text { - Blanket (untested) assumption of } \\
\text { risk aversion, without due } \\
\text { consideration of diverse } \\
\text { outcomes (e.g., risk aversion can } \\
\text { lead to a choice of distant as well } \\
\text { as proximate markets, depending } \\
\text { on strategic objectives). }\end{array}$ & $\begin{array}{l}\text { Similar to the issue of entry mode } \\
\text { choice, it appears that differences } \\
\text { in internal and external contexts } \\
\text { must be considered in order to } \\
\text { explain international location } \\
\text { choices in family firms. Specifically, } \\
\text { micro-level characteristics } \\
\text { (cognitive make-ups, personal } \\
\text { objectives, and biases) often } \\
\text { explain diverging results in terms of } \\
\text { family firms' location preferences. } \\
\text { Overall, no generalized relationship } \\
\text { can be reasonably established, with } \\
\text { contextual features of family firms } \\
\text { affecting their location choices. }\end{array}$ \\
\hline $\begin{array}{l}\text { Internationalization } \\
\text { process }\end{array}$ & $\begin{array}{l}\text { - Family firms pursue a traditional/ } \\
\text { stepwise internationalization } \\
\text { model. } \\
\text { - Under certain conditions, family } \\
\text { firms internationalize rapidly/ } \\
\text { pursue non-traditional } \\
\text { internationalization patterns } \\
\text { (e.g., firms where stewardship } \\
\text { attitude is weak or moderate). } \\
\text { - Family firms learn about } \\
\text { international opportunities } \\
\text { through accidental discovery. } \\
\text { - Family firms can be proactive in } \\
\text { international opportunity } \\
\text { recognition, depending on the } \\
\text { level of their international }\end{array}$ & $\begin{array}{l}\text { - Contextual differences: expansion } \\
\text { patterns are context-specific. } \\
\text { - The nature of social capital } \\
\text { utilized (existing/narrow versus } \\
\text { new/broad) explains different } \\
\text { patterns in international } \\
\text { opportunity recognition. }\end{array}$ & $\begin{array}{l}\text { Expansion patterns are } \\
\text { idiosyncratic and are shaped by a } \\
\text { number of complex heterogeneous } \\
\text { characteristics at various levels of } \\
\text { analysis. Differences in findings are } \\
\text { typically explained by } \\
\text { heterogeneous variables linked to } \\
\text { individual family members, } \\
\text { families, firms or the international } \\
\text { contexts within which the } \\
\text { expansion is undertaken. Most } \\
\text { studies focusing on } \\
\text { internationalization process } \\
\text { attempt to achieve a deeper } \\
\text { understanding of the process and } \\
\text { its determinants, rather than }\end{array}$ \\
\hline
\end{tabular}


Table 2 (Continued)

\begin{tabular}{|c|c|c|c|}
\hline Core IB theme & Main findings/perspectives & Sources of contradiction & Comments \\
\hline & $\begin{array}{l}\text { orientation and the breadth of } \\
\text { social capital. } \\
\text { - Expansion patterns depend on } \\
\text { individual factors (characteristics, } \\
\text { capabilities, attitude), family- } \\
\text { specific factors (generational } \\
\text { quality and vision, stewardship } \\
\text { attitudes, harmony), firm-specific } \\
\text { factors (business models and } \\
\text { strategies, capabilities, internal } \\
\text { governance, quality of networks, } \\
\text { historical origins) and macro-level } \\
\text { factors (home and host country } \\
\text { and global environments/ } \\
\text { tensions). }\end{array}$ & & $\begin{array}{l}\text { assigning a generalized } \\
\text { internationalization pattern to } \\
\text { family firms. Such a generalized } \\
\text { relationship cannot reasonably be } \\
\text { established. }\end{array}$ \\
\hline $\begin{array}{l}\text { Pace and rhythm of } \\
\text { internationalization }\end{array}$ & $\begin{array}{l}\text { - Family firms internationalize } \\
\text { slowly, following a traditional } \\
\text { stepwise pattern. } \\
\text { - Timing of family firm } \\
\text { internationalization does not fall } \\
\text { into a distinct pattern. } \\
\text { - Timing of entry depends on stage } \\
\text { of internationalization: there is no } \\
\text { differences between timing of } \\
\text { entry between family and } \\
\text { nonfamily firms in the initial } \\
\text { exporting stage, but family firms } \\
\text { enter into the advanced phase of } \\
\text { exporting later than nonfamily } \\
\text { ones. } \\
\text { - Family ownership speeds up the } \\
\text { pace of internationalization, but } \\
\text { negatively affects its rhythm. } \\
\text { - Features impacting pace and } \\
\text { rhythm of internationalization } \\
\text { include: founders' mindset, firm } \\
\text { strategy, governance, managerial } \\
\text { practices, succession practices } \\
\text { and generational features, } \\
\text { technological capabilities, } \\
\text { location characteristics. }\end{array}$ & $\begin{array}{l}\text { - Contextual differences: expansion } \\
\text { patterns (including timing) are } \\
\text { context-specific. } \\
\text { - Different methodologies and } \\
\text { benchmarks/definitions of 'speed' } \\
\text { (pace) and 'rhythm'. } \\
\text { - Differences in features related to } \\
\text { other aspects of } \\
\text { internationalization, e.g., scale } \\
\text { and scope. }\end{array}$ & $\begin{array}{l}\text { Studies that consider } \\
\text { heterogeneous contextual features, } \\
\text { both internal and external, arrive at } \\
\text { nuanced conclusions that } \\
\text { challenge the conventional thesis } \\
\text { that family firms internationalize } \\
\text { slowly in a gradual/stepwise } \\
\text { fashion. Still, establishing a } \\
\text { generalized pattern for temporal } \\
\text { features of family firm } \\
\text { internationalization is not possible } \\
\text { without considering nuanced } \\
\text { contextual features. Diverging } \\
\text { results re: the timing, speed and } \\
\text { rhythm of internationalization stem } \\
\text { from contextual differences related } \\
\text { to other aspects of } \\
\text { internationalization: for example, } \\
\text { family firms with narrow } \\
\text { international scope may pursue } \\
\text { more rapid internationalization } \\
\text { than firms with greater } \\
\text { international scope. }\end{array}$ \\
\hline $\begin{array}{l}\text { Internationalization } \\
\text { performance }\end{array}$ & $\begin{array}{l}\text { - Family control negatively impacts } \\
\text { profitability through a negative } \\
\text { impact on internationalization. } \\
\text { - Proportion of family members in } \\
\text { TMTs and international } \\
\text { diversification have a joint }\end{array}$ & $\begin{array}{l}\text { - Inconsistent operationalization of } \\
\text { internationalization (scale versus } \\
\text { scope; lack of consideration of } \\
\text { international diversification). } \\
\text { - Limited consideration of } \\
\text { internationalization motives (e.g., } \\
\text { nonfinancial objectives of }\end{array}$ & $\begin{array}{l}\text { Most studies investigating } \\
\text { internationalization performance } \\
\text { outcomes focus on financial } \\
\text { performance. Establishing a } \\
\text { generalized internationalization- } \\
\text { financial performance relationship } \\
\text { is problematic due to diverging }\end{array}$ \\
\hline
\end{tabular}


Table 2 (Continued)

\begin{tabular}{|c|c|c|c|}
\hline Core IB theme & Main findings/perspectives & Sources of contradiction & Comments \\
\hline & $\begin{array}{l}\text { negative impact on firm } \\
\text { performance. } \\
\text { - Internationalization enhances } \\
\text { family firms' performance. } \\
\text { - Family management positively } \\
\text { moderates the relationship } \\
\text { between internationalization, } \\
\text { innovation, and performance. } \\
\text { - Market value decrease caused by } \\
\text { overseas asset value decrease is } \\
\text { weaker for family firms than } \\
\text { nonfamily ones. } \\
\text { - The relationship between family } \\
\text { influence and performance is } \\
\text { contingent on geographic and } \\
\text { cultural distance between home } \\
\text { and host countries. } \\
\text { - Family firms with family leaders } \\
\text { perform better when } \\
\text { internationalization is home } \\
\text { region-focused; family firms with } \\
\text { nonfamily leaders perform better } \\
\text { outside of the home regions. } \\
\text { - International performance is } \\
\text { determined by international } \\
\text { entrepreneurship orientation, } \\
\text { managerial routines, and } \\
\text { governance practices. } \\
\text { - Internationalization of family } \\
\text { firms promotes growth but harms } \\
\text { short-term profitability. } \\
\text { - Family firm internationalization } \\
\text { promotes CSR. } \\
\text { - The achievement of } \\
\text { internationalization goals hinges } \\
\text { on managerial skills, innovation } \\
\text { capacity, absorptive capacity, and } \\
\text { adaptability. }\end{array}$ & $\begin{array}{l}\text { internationalization) when } \\
\text { operationalizing performance. } \\
\text { - Inconsistent definition of financial } \\
\text { performance; international } \\
\text { performance not isolated. } \\
\text { - Static operationalization of } \\
\text { financial performance. } \\
\text { - Inconsistent operationalization of } \\
\text { family firms (ownership versus } \\
\text { control versus influence) } \\
\text { - Contextual } \\
\text { differences/contingencies. }\end{array}$ & $\begin{array}{l}\text { definitions and measures of both } \\
\text { internationalization and } \\
\text { performance, and the fact that the } \\
\text { relationship is moderated by } \\
\text { idiosyncratic firm-level features. } \\
\text { Introducing the family variable into } \\
\text { the relationship creates further } \\
\text { complications due to inconsistent } \\
\text { definitions of family firms, and the } \\
\text { addition of an extra source of } \\
\text { heterogeneity at the family level. } \\
\text { Due to the inherent heterogeneity } \\
\text { of firms and their internal and } \\
\text { external contexts, tracing a } \\
\text { generalized relationship between } \\
\text { family firm internationalization and } \\
\text { performance is theoretically and } \\
\text { empirically untenable. A more } \\
\text { nuanced approach is required, } \\
\text { including an in-depth investigation } \\
\text { of moderators and contingencies, } \\
\text { and an inclusion of non-financial } \\
\text { performance outcomes. Reviewed } \\
\text { studies investigating non-financial } \\
\text { outcomes of family firm } \\
\text { internationalization focused on } \\
\text { different objectives such as } \\
\text { corporate philanthropy and } \\
\text { inheritance. }\end{array}$ \\
\hline
\end{tabular}

Jacobson, \& Moyano-Fuentes, 2007: 106). GómezMejía et al. (2007) and others (e.g., Chirico, GómezMejia, Hellerstedt, Withers, \& Nordqvist, 2020) present evidence suggesting that family-owner managers are so averse to the loss or reduction of SEW that they are willing to forego a certain amount of profit in order to preserve it. However, the effects of this loss aversion on family firm internationalization are not clear. Gómez-Mejía et al. (2010: 224) note that "family firms are pulled in two opposite directions" by SEW, because international diversification lowers both business risk (thus helping preserve SEW) and family control (thus reducing SEW). However, Gómez-Mejía et al.'s empirical results show that, on average, family involvement is associated with lower international scale. Other SEW-based studies reach similar conclusions, both when analyzing internationalization through export (Bannò \& Trento, 2016; Dou, Jacoby, Li, Su, \& Wu, 2019; Kraus, Mensching, Calabrò, Cheng, \& Filser, 2016; Ray, Mondal, \& Ramachandran, 2018) and FDI (Baronchelli, Bettinelli, Del Bosco, \& Loane, 2016; Carney, van Essen, Gedajlovic, \& Heugens, 2015). 
The literature suggests that a more nuanced approach to questions concerning the influence of specific attributes on the scale of family firm internationalization may help resolve some of these contradictions. For example, internationalization requires extensive managerial resources (Hitt, Bierman, Uhlenbruck, \& Shimizu, 2006), which are frequently lacking in family firms due to their heavy reliance on family leadership and, also, their compensation practices (Neckebrouck, Schulze \& Zellweger, 2018). A series of studies document that individual-level characteristics of family managers, such as education and prior international work experience, positively influence international scale (Casillas \& Acedo, 2005; Majocchi, D'Angelo, Forlani, \& Buck, 2018; RamónLlorens, García-Meca, \& Duréndez, 2017). Risk aversion and reluctance to reduce family owners' control of the firm (Fernández \& Nieto, 2005; Gómez-Mejía et al., 2010; Schulze, Lubatkin, Dino, \& Buchholtz, 2001; Sciascia, Mazzola, Astrachan, \& Pieper, 2012) also limit the family firm's access to the financial resources needed for internationalization. Family firms can increase their access to the managerial and financial resources needed to develop their international scale by involving outside (i.e., nonfamily) parties in firm governance (Arregle, Naldi, Nordqvist, \& Hitt, 2012), and by raising external capital from minority domestic and foreign shareholders (Dick, Mitter, Feldbauer-Durstmüller, \& Pernsteiner, 2017; Majocchi et al., 2018). Outside board members are an important source of experience, knowledge, and professional skills (Calabrò, Mussolino, \& Huse, 2009; Purkayastha, Manolova, \& Edelman, 2018; Sundaramurthy \& Dean, 2008). Their positive influence on international scale is also associated with their impact on board dynamics: the presence of outsiders is associated with reduced principal-principal agency conflict (that is, among family and non-family shareholders; Calabrò, Torchia, Pukall, \& Mussolino, 2013; Singla, George, \& Veliyath, 2017) and with increased rationality, professional conduct, and more careful consideration of strategic options (Herrera-Echeverri, Geleilate, GaitanRiaño, Haar, \& Soto-Echeverry, 2016; Majocchi \& Strange, 2012). Minority foreign investors are also a valuable source of international market knowledge (Fernández \& Nieto, 2006). Hence, both outside directors and nonfamily ownership are positively related to family firms' international scale.

Scholars agree that family firms' social capital also influences international scale. However, the nature of social capital's impact is complex. Generally, a family firm's organizational social capital is uniquely influenced by the family's social capital (Arregle et al., 2007), which is characterized by devotion, generosity, solidarity, and close social interactions among family members (Bourdieu, 1994). Such family firm's social capital lowers monitoring costs, reduces relational risk, and allows family firms to develop effective informal mechanisms (Mustakallio, Autio, \& Zahra, 2002) that reduce their cost of governance. It also facilitates knowledge sharing, expands firm-level relational capital (Arregle et al., 2007; Dyer \& Singh, 1998; Kano, Ciravegna, \& Rattalino, 2021), increases the speed of decision-making (Gallo \& Pont, 1996), and facilitates family firm access to international knowledge and host country networks (Basly, 2007; Cheong, Lee, \& Lee, 2015). Hence, it positively influences their international scale. However, strong forms of family social capital can also hinder internationalization. Strong family social capital can lead to groupthink (Janis, 1982), amoral familism (the systematic and dysfunctional distrust of outsiders; Banfield, 1958), and strategic hyper-simplicity (the overspecialization on a simple competitive repertoire undermining adaptation and performance; Miller \& Chen, 1996). Those factors, when combined with the limited diversity of family managers' social capital and professional experience, can reduce networking and constrain the firm's capabilities (Stadler, Mayer, Hautz, \& Matzler, 2018) and international scale. It follows that whether or not family firms' social capital assists in developing international scale depends on specific uses of social networks in each firm, particularly in relation to other types of resources.

Scholars also disagree about which generation of family leadership is more likely to increase international scale (Bannò \& Trento, 2016; Dou et al., 2019; van Essen et al., 2015). Claver, Rienda, and Quer (2008) hold that first-generation owners and managers are more risk tolerant and more likely to support internationalization. Others (Cristiano, 2018; Fang, Kotlar, Memili, Chrisman, \& De Massis, 2018; Okoroafo \& Perryy, 2010) find that succeeding generations of family leaders may be more open to new ideas and growth opportunities and thus contribute to increasing internationalization. We suspect that these divergent results can be explained by addressing specific characteristics of each generations (e.g., levels of education, aspirations, extant international experience), as well as by other heterogeneous characteristics of firms 
(e.g., family ownership concentration, inheritance rules, minority shareholder protection). These conjectures await rigorous testing.

Hennart et al. (2019) contend that, although family firms on balance tend to be less international, those that focus on high-quality niche products may be well positioned on a global scale. A focus on high-quality niche products helps family firms overcome idiosyncratic internationalization constraints and allows them to leverage their unique capabilities. Hennart et al. (2019) find that family firms pursuing a high-quality global niche business model achieve similar internationalization (exports) as their nonfamily counterparts. Eddleston, Sarathy, and Banalieva (2019) elaborate that such niche strategies work best for professionalized family firms located in countries with a comparatively strong reputation for quality. More generally, the conclusions by Eddleston et al. (2019) point to the moderating role of macro-level formal and informal institutions and firm-level governance practices.

A number of studies confirm that a variety of institutional attributes moderates international scale. With regard to formal institutions, Arregle et al. (2017) argue that greater minority shareholder protection in the home country exacerbates the negative family firm-internationalization relationship. More specifically, greater protection offers minority shareholders an enhanced opportunity to monitor family activity, which harms the relationship between minority shareholders and majority family owners and, consequently, reduces access to resources that family firms need to internationalize. Lehrer and Celo (2017) suggest that national institutional characteristics (i.e., favorable inheritance rules, overall export orientation of the economy, and symbiotic relations between family firms and large internationalized nonfamily firms) help explain the high internationalization level of German family firms.

Among the few studies that investigate the impact of informal institutions, Arregle et al. (2019) suggest that family-level background characteristics, such as family structure, history, and values/traditions, influence international scale. Similarly, soft factors like trust towards other countries ("generalized trust") (Arregle et al., 2017) and a family-oriented political ideology of government (Duran, Kostova, \& van Essen, 2017) are positively related to family firms' international scale. Studies incorporating macro-level variables generally conclude that family firm internationalization is context-dependent, and that cross-country institutional differences are critical to explaining the relationships between family ownership-management and internationalization.

In sum, existing research has not identified a consistent generalized relationship between family involvement and international scale. Recently, scholars have argued that the search for a general relationship (i.e., whether family firms are indeed more or less internationalized than non-family ones) is an elusive, if not futile, task. For example, Kano and Verbeke (2018) note that the theoretical challenge of establishing a general relationship between family owner-management and internationalization is impossibly complicated by the heterogeneity of family firms. Further, a large-scale meta-analysis by Arregle et al. (2017) found no evidence of a generalized relationship between family owner-management and international scale. Instead, it confirmed that the nature of the relationship (facilitating versus constraining) is determined by a number of firm- and institutional-level idiosyncratic features. As a result, researchers have turned their attention to the effects of specific variables on family firms' international scale, or to the exploration of complex and non-linear patterns in those relationships (see Almodóvar, Verbeke, \& Rodríguez-Ruiz, 2016; Mitter, Duller, FeldbauerDurstmüller, \& Kraus, 2014; Sciascia et al., 2012).

\section{Explaining Family Firms' International Scope}

Unlike broader IB research, most research on international family business does not conceptually or empirically differentiate between international scale and scope. Therefore, the rationales, contingencies, and variables described in the preceding section on 'international scale' are, for the most part, assumed to apply to the international scope of the family firm. However, several studies specifically account for international scope, proposing more precise and robust theoretical mechanisms and delivering empirical results that diverge from those summarized earlier. For example, Alessandri, Cerrato, and Eddleston (2018) conclude that family involvement is associated with greater home region orientation, while Arregle et al. (2017) and others (Avrichir, Meneses, \& dos Santos, 2016; Bauweraerts \& Vandernoot, 2019) specifically associate it with reduced scope of internationalization. In contrast, Zahra (2003) initially speculated, based on stewardship theory, that family involvement should have a positive effect on international scope, but this paper actually found that the effects 
of ownership and management differ: ownership exerted a positive effect on international scope, and management a negative one. Given that Zahra's findings challenge key assumptions of the stewardship theory used to develop hypotheses, we address the implications of this study in the assessment section of this article (see also Table 2).

In the main, scholars offer four theoretical arguments to account for lower international scope among family firms. First, Xu, Hitt, and Dai (2020a) argue that increasing international scope creates higher demands on resources, which increases the risk of SEW losses. Second, family leaders are motivated to use their personal business networks to facilitate internationalization, and they tend to prioritize high network trust and high collaboration intensity (Cesinger, Hughes, Mensching, Bouncken, Fredrich, \& Kraus, 2016). However, since these personal network ties tend to be limited and regionally bound, international scope tends to be restricted (Jimenez, Majocchi, \& Della Piana, 2019; Tsang, 2020) or constrained to a particular region (Banalieva \& Eddleston, 2011). Third, increased international diversity requires greater international experience on the part of family members, as well as access to additional capabilities and resources. However, strong family social capital can hinder international scope by limiting the range of available managerial capabilities in a family firm. It can lead to a mismatch between the pool of competencies available in family managers' social networks and the growing diversity needed for international scope expansion, which reinforces the liability of foreignness for family firms (D'Angelo, Majocchi, \& Buck, 2016; Stadler et al., 2018). Finally, strong family social capital helps perpetuate the imprint of the founder on strategy across generations of leadership, which can limit changes in international scope (Suman, 2017).

Other studies explored the impact of outsiders, such as non-family managers, investors, and board members, on international scope. D'Angelo et al. (2016) find that outsiders can provide the bridging and bonding social capital needed to promote international scope, but that these benefits from outsiders are moderated by the level of family influence. In family-influenced firms (that is, those in which the family lacks unilateral control), outsiders have a positive influence on international scope; the positive effects of family governance can combine synergistically with their presence. This positive influence does not hold true in familycontrolled firms due to internal family dynamics and, in many cases, conflicting objectives (e.g., dominant family owner-managers strategic choices may be driven by identity-related concerns such as SEW), differing value systems (e.g., the moral order of kinship versus 'amoral' motives like shareholder value maximization; Sirmon \& Hitt, 2003), and bifurcation bias (defined as a systemic preferential treatment of family assets over nonfamily ones; Kano \& Verbeke, 2018). ${ }^{7}$ Additionally, as aforementioned, a strategic positioning on high-quality niche products can help these family firms to overcome their internationalization constraints (Hennart et al., 2019) and achieve similar international scope as their nonfamily counterparts.

Overall, our review suggests that the international scope of family firms is more constrained than that of nonfamily firms. While the involvement of external actors can alleviate some constraints and positively moderate the international scope of family firms, the level of family involvement and strategic objectives of the family firm are also influential. Studies on family firm international scope show a strong degree of consensus on the effects of various variables related to family owner-management, unlike studies examining other aspects of internationalization.

\section{Explaining Family Firms' International Entry Modes}

A significant number of studies $(18 \%$ of the reviewed articles) investigate the influence of family ownership and management on international entry mode choice and partner selection. In the main, researchers assume that family firm owners and managers are inherently risk averse and will tend to adopt entry mode strategies that minimize various risks, such as committing too many resources to a single venture (Filatotchev, Strange, Piesse, \& Lien, 2007) or dealing with uncertainty (Kao \& Kuo, 2017; Kao, Kuo, \& Chang, 2013; Kuo, Kao, Chang, \& Chiu, 2012). Family firms may also select entry modes that minimize the risk of SEW dissipation (e.g., Monreal-Pérez \& Sánchez-Marín, 2017; Scholes, Mustafa, \& Chen, 2016). However, different theoretical perspectives suggest that risk aversion may lead to different entry mode preferences.

Studies that approach entry mode choice from a comparative institutional analysis perspective (i.e., transaction cost economics (TCE) and internalization theory) suggest that family firms use cooperative entry modes as a way to address risks associated with low levels of foreign experience 
(Kuo et al., 2012). Sestu and Majocchi (2020) argue that joint ventures (JV) are more likely when both potential partners are family-owned and managed. A family firm typically own some family-related idiosyncratic assets (such as reputational assets or a long-established network of relationships) that are embedded in the firm and therefore difficult to trade. As such, when assets owned by family firms in different countries are complementary and bundled, a JV is the only efficient governance solution. The decision further depends on the presence of bifurcation bias and on the type of assets deployed in host countries (Kano \& Verbeke, 2018; Verbeke $\&$ Kano, 2012). Kano and Verbeke argue that when transferring 'heritage' assets, i.e., those that hold an emotional/affective meaning for the family, family firms are likely to choose entry modes that maximize control, such as wholly owned subsidiaries (WOS), in order to protect these assets. On the other hand, when transferring 'commodity' assets, family firms will seek entry modes that afford the maximum profit potential, regardless of the actual value, contribution, and vulnerability of the assets deployed. Studies using agency theory suggest that high resource commitment entry modes, such as WOS, expose the family firm to problems associated with adverse selection (e.g., supply chain partner quality may be difficult to determine ex ante) and hold-up (e.g., enforcement of contract and other legal issues can make WOS costly to exit). These issues increase agency costs (Filatotchev et al., 2007) and prevent family firms from committing extensive resource bundles in host countries.

SEW-framed studies diverge on the effects of SEW on family firms' foreign entry mode choices. Some scholars assert that family firms prefer to enter foreign markets through low commitment modes such as export in order to minimize the potential SEW dissipation risk associated with FDI (MonrealPérez \& Sánchez-Marín, 2017; Scholes et al., 2016). However, WOS afford family firms greater control over operations and therefore may be preferred by family firms that seek to protect SEW (Abdellatif, Amann, \& Jaussaud, 2010; Pongelli, Calabrò, \& Basco, 2019; Pongelli, Caroli, \& Cucculelli, 2016). Pongelli et al. (2016) note, however, that entry preference is likely influenced by family ownership structure, as well as the weight placed by the family on SEW preservation. Scholars have pointed out a family firm paradox in the realm of international JV formation: family firms seem to have a lower willingness to form international JVs, due to the desire to preserve control, even if they have a higher ability to govern them due to their superior relational capabilities (Debellis, De Massis, Petruzzelli, Frattini, \& Del Giudice, 2020). Further, the establishment choice for WOS - the choice between a greenfield and an acquisition - has also been investigated, with the majority of studies concluding that family firms prefer greenfield entry to acquisitions, so as to avoid complex acquisition integration processes and maintain full control over the subsidiary, that is, its staffing, organizational design, structure, partnerships, and established routines (Boellis, Mariotti, Minichilli, \& Piscitello, 2016; Yamanoi \& Asaba, 2018). Boellis et al. (2016) further clarify that the preference is less pronounced in family-owned (rather than familymanaged) firms, which are more likely to seek access to external equity to finance the acquisition, and to have professional managers with the requisite integration skills.

The Uppsala model of internationalization (Johanson \& Vahlne, 1977, 2009; Vahlne \& Johanson, 2017) suggests that psychic distance, as well as the liability of outsidership and associated difficulties in penetrating host country networks, shape patterns and modes of international expansion. Kontinen and Ojala (2010), using the Uppsala lens to study family firms' entry mode choices, argue that family firms exhibit greater cautiousness when entering psychically distant markets by choosing indirect (i.e., non-equity) entry modes. Family firms may subsequently deepen their commitments to foreign markets through FDI. Similarly, Stieg, Cesinger, Apfelthaler, Kraus, and Cheng (2018) observe that, as a family firm's FDI commitment to foreign markets grows, the firm faces the challenge of shifting its natural emphasis from an internal focus on preserving family harmony to building external networks and resources. This may slow the family firm's progression toward highercommitment operating modes in foreign markets.

Entry mode decisions in family firms are multidimensional and contingent on, inter alia, the timing of entry, strategic considerations, and macrolevel variables. Further, mode choices are dynamic and may evolve through different stages of international expansion. Several recent studies highlight these nuances and contingencies of operating mode dynamics in family firms. For example, $\mathrm{Xu}$, Hitt, and Miller (2020b), introduce decision-making stage as a moderating variable, holding that, in the first stage (entry mode decision), family firms prefer JVs compared to 
WOS, because the former entail lower financial risks and preserve SEW. In the second stage (i.e., establishment mode decision), the level of family ownership positively influences the likelihood of choosing acquisition as the entry mode; acquiring an ongoing business with access to local networks and markets potentially increases financial returns while reducing threats to SEW. Motivation for foreign expansion also plays a role: family firms that enter foreign markets with a strategic asset seeking motive may show a greater propensity for acquisitions as a way to quickly obtain complementary assets and catch up with international competitors - a strategy that may be more pronounced among family firms in emerging economies (Rienda, Claver, Quer, \& Andreu, 2019).

IB research has long established that firm boundaries depend on macro-level characteristics of home and host countries, with institutions playing a critical role in multinational enterprises' (MNEs') entry mode strategies (Brouthers \& Hennart, 2007). Consequently, institutional variables are used to explain the contextual effects moderating the relationships between family firms' characteristics and their entry mode decisions. Such variables include the home country's national business systems (i.e., coordinated versus market economies, Geppert, Dörrenbächer, Gammelgaard, \& Taplin, 2013), stage of economic development (e.g., family firms from emerging countries especially favor acquisitions when entering developed countries), and the corporate governance practices and rules perceived as legitimate (Luo, Chung, \& Sobcza, 2009). Foreign partners whose home country institutional logic more closely resembles family governance principles are probably more open to JVs with family firms.

To summarize, our review suggests that family firms do not exhibit a de facto preference for a particular entry mode. The aggregate analysis of studies addressing family firms' entry mode choice is consistent with a conceptualization of operating modes proposed by Benito, Petersen, and Welch (2009): Similar to the case of MNEs with dispersed ownership, family firms choose bundles and packages of entry modes based on internal and external contextual factors. These modes are adjusted over time as a function of changing internal and external environments and firms' evolving experiences. Our view is that many of the conflicting results presented in this section are likely driven by contextual differences among samples. The prospect that other perspectives may lend further insight is addressed later in this article.

\section{Explaining Family Firms' International Location Choice}

Location and entry mode selection are distinct yet interrelated decisions (Benito et al., 2009). As with studies addressing entry mode choice, studies that investigate family firms' location choice yield mixed findings, partially due to the fact that risk aversion, along with SEW, may lead to different internationalization paths depending on a firm's strategic objectives. For example, Lien and Filatotchev (2015) observe that high levels of family ownership tend to be associated with higher-risk FDI locations, and attribute this effect to the fact that large block shareholding in family-owned firms facilitates increased monitoring capability and can thus mitigate agency conflicts associated with managerial risk aversion. On the other hand, family firms may favor home regions and culturally similar foreign locations (seen as less risky) in order to protect their equity and their SEW (Baronchelli et al., 2016; Gómez-Mejía et al., 2010; Procher, Urbig, \& Volkmann, 2013; Strange, Filatotchev, Lien, \& Piesse, 2009).

Attention to internal (cognitive) and external (market-based) contextual heterogeneity helps reconcile conflicting results. For example, Boers (2016) posits that psychic distance impacts location choice, but his qualitative study establishes no de facto preference for low psychic distance locations in family firms. Rather, he finds that market choice is strongly influenced by another internal contextual factor - the risk preference of the controlling family. Kano and Verbeke (2018) argue that yet another internal contextual factor, bifurcation bias, influences location choice. They posit that strong bifurcation bias motivates family firms to choose FDI destinations based on a family's personal preferences, the presence of family networks, and the type of assets invested overseas. The transfer of 'heritage' assets will lead bifurcation-biased firms to favor locations that allow ownership of operations by foreign investors. In contrast, unbiased family firms (that is, those that implement routines to safeguard against potential bifurcation bias, and in which internationalization decisions are driven by comparative efficiency considerations) choose foreign markets based on location advantages. In this case, family firms do not display unique location choice patterns. 
As such, we conclude from our literature review that no consistent generalized relationship between family ownership/control and location choices has been established. Rather, evidence suggests differences in external contexts and across firms account for diverging decisions in the realm of international location choice.

\section{Explaining Family Firms' Internationalization Process}

The majority of reviewed studies conclude that family firms tend to pursue a traditional, stepwise internationalization model (Graves \& Thomas, 2008; Kontinen \& Ojala, 2010, 2012), starting with entry through lower-commitment modes, usually in more psychically proximate countries (Claver, Rienda, \& Quer, 2008). Patterns of gradual, stepwise expansion are attributed to the challenge of overcoming resource constraints and acquiring the managerial skills, knowledge, and experience needed to compete in international markets (Minetti, Murro, \& Zhu, 2015). These constraints make it difficult for family firms to overcome the liability of foreignness in distant markets. Family owners' risk attitudes also help explain the preference for stepwise internationalization.

However, a number of reviewed papers identify factors that might cause family firms to internationalize rapidly or to pursue nontraditional internationalization patterns. For example, Hennart et al. (2019) note that family firms selling massmarket products that require extensive adaptation in host markets suitably adopt a stepwise internationalization process; nonetheless, family firms pursuing a global high-quality niche strategy can quickly reach high scale and scope of internationalization through export. Kontinen and Ojala (2012) find that, whereas strong stewardship is associated with a stepwise process, weak/moderate stewardship attitudes within the family firm are correlated with so-called 'born global' or 'bornagain global' patterns of internationalization. Meanwhile, Stieg, Hiebl, Kraus, Schüssler, and Sattler's (2017) study 'born-again global' family firms and conclude that succeeding generations of family firm leadership, assuming the requisite education and experience, often re-commit the firm to its original strategic orientation and engage in quick and extensive internationalization. Fernández-Moya (2010) describes early and intense internationalization at the successful Spanish publishing house Salvat; the firm's quick evolution from a small family business to a large family- owned MNE was supported by capacities for technological and managerial innovation, diverse social networks, and the professionalization of the firm's management.

More broadly, the international expansion process is thought to follow specific pathways determined by individual, family, organizational, and environmental factors. Individual factors refer to such characteristics of family members as capabilities, stewardship attitudes, and vision and quality of the next generation. At the family level, family aspirations and the degree of family harmony play a role (Graves \& Thomas, 2008). Organizational factors include strategic considerations, required resources and capabilities, quality of human capital, openness of governance (Casillas, Moreno, \& Acedo, 2010), historical origins of the firm (HuescaDorantes, Michailova, \& Stringer, 2018), and the nature of relationships within and outside the firm (Cristiano, 2018). Environmental factors encompass various characteristics of the home and host country environment, such as socio-geographic factors, the economic and cultural heritage of home countries, and prevailing cultural values in home and host societies (Shapiro, Gedajlovic, \& Erdener, 2003; Verbeke, Yuan, \& Kano, 2020).

Intergenerational involvement emerged as a key, but controversial, feature shaping the internationalization process (Graves \& Thomas, 2008). Okoroafo (1999) argues that family firms that do not internationalize in the first and second generations are unlikely to do so in later generations. In contrast, Calabrò, Brogi and Torchia (2016) and Cristiano (2018) argue that the involvement of incoming generations positively influences exploration and exploitation of international opportunities, as later generations are more risk tolerant and may be more open to new ideas. However, this effect is contingent on a variety of family attributes, such as the relationships between generations, objectives of the incoming generation, and levels of education and international experience (Stieg et al., 2017).

Several studies focus on specific features of the internationalization process, such as international opportunity recognition. Here, the findings split again. Zaefarian, Eng, and Tasavori (2016) argue that family firms do not proactively initiate international opportunity identification (a conclusion echoed in Ratten \& Tajeddini, 2017), but rather learn about cross-border opportunities through accidental discovery, e.g., information acquired through acquaintances and social networks. 
Marinova and Marinov (2017) arrive at the opposite conclusion, concluding that most family firms in their study proactively sought international clients. Proactive behavior is linked to the family's international orientation and commitment, as well as to the breadth of its social capital. Similarly, Kontinen and Ojala (2011) observe that firms recognized international opportunities when they established new formal ties but failed to do so when they relied on existing informal or family ties.

Finally, learning is a key determinant of the internationalization process, as illustrated in a rich historical study of large Spanish family firms by Puig and Pérez (2009). The authors find that a firm's learning process is path-dependent and strongly shaped by major historical events, local and global tensions, and ongoing trends in globalization (see also Castagnoli, 2014). Family firms that internationalized successfully are able to learn managerial lessons from traditional corporations and to adapt to the external environment by diversifying and changing specializations and market niches. Maintaining strong links to local, national and international networks emerged as a critical factor in survival and growth of family firms. These links (often aided by collective action, such as large family lobby groups) facilitated global commercial and political knowledge sharing, fundamental for the development of family capitalism (Harlaftis \& Theotokas, 2004; Pérez \& Puig, 2009).

We conclude that family firms' international expansion does not follow a particular generalized pattern. Collectively, the studies indicate that internationalization patterns and processes in family firms are idiosyncratic and shaped by history as well as a variety of family, organization, and environment-level variables. Family firm differences across these variables explain the contradicting results discussed above.

\section{Explaining Temporal Aspects Of Family Firms' Internationalization}

Some studies in our sample focused specifically on exploring the pace, rhythm (the regularity of foreign expansion), and timing (early versus later in a firm's development) of family firm internationalization. While it is often assumed that family firms internationalize slowly and follow a stepwise pattern of international expansion (Graves \& Thomas, 2008), studies focusing on temporal dimensions of family firm internationalization suggest that the process is more nuanced. For example, Lin (2012) shows that family ownership increases the pace of internationalization but throws off its rhythm (i.e., internationalization becomes more irregular). Stieg et al. (2017) find that the timing of internationalization is linked to generational successions, but its pace is shaped by successor attributes, such as the successor's international experience and education level. Kontinen and Ojala (2012) suggest that higher levels of ownership concentration following succession correspond with a greater pace of internationalization. In sum, our review suggests that the temporal patterns of family firm internationalization are contingent on characteristics of the family firm (e.g., ownership concentration, succession, successor attributes), and probably moderated by other dimensions of the internationalization process, including its scale, scope, and stage.

\section{Explaining Family Firms' Internationalization Performance}

Studies that investigate family firm internationalization performance mainly focus on financial outcomes (see Appendix 1). As expected, findings about the effects of family firms' internationalization on performance are mixed, with some reporting positive (e.g., Stadler, Mayer, Hautz, \& Matzler, 2018; van Essen et al., 2015) and others negative effects (Graves \& Shan, 2014; Hsu, Kao, \& Lee, 2016; Tsao \& Lien, 2013). Explanations for these outcomes range from the agency benefits of family governance on financial performance (Hsu et al., 2016) to the constraining effects of family firm's social networks (Stadler et al., 2018). Seeking to reconcile divergent findings, researchers have turned their attention to international performance contingencies. Mensching, Calabrò, Eggers, and Kraus (2016) show that, the greater the family influence, the more likely the overall perceived success of internationalization; yet these results only apply to host countries with low geographic and cultural distances. Similarly, Banalieva and Eddleston (2011) find that family firms led by family members report higher performance when pursuing a high home region orientation focus, whereas nonfamily leaders generate better performance for family firms expanding outside of the home region. Hernández-Perlines, Moreno-García, and Yañez-Araque (2016) and Hernández-Perlines and $\mathrm{Xu}$ (2018) find that international entrepreneurship orientation (IEO) largely explains international performance of family businesses, with innovation the most important dimension of IEO. This IEO-performance relationship is positively 
mediated by absorptive capacity and by the firm's environment. Fernández-Moya (2010), Pérez and Puig (2009), and Puig and Pérez (2009) focus on non-financial outcomes of internationalization, such as the evolution of a small family firm into a large family-owned MNE and the successful integration of family-owned firms into the global economy. These papers find that these desirable outcomes are shaped by several factors: managerial skills, capacity for innovation, learning, and ability to adapt to environmental changes. Finally, Lu, Liang, Shan, and Liang (2015) discover that the internationalization of Chinese family firms promotes medium-term growth (i.e., over 3 years) but harms short-term profitability due to firms' resource constraints and the mistakes they make in the learning process.

More generally, some scholars argue that due to the inherent heterogeneity of firms in general, and family firms in particular, the search for a general relationship between internationalization and financial performance is a conceptual and empirical nonstarter (Hennart, 2007; Verbeke \& Brugman, 2009). These scholars advocate a more nuanced approach to studying the performance of family firm internationalization, including a focus on non-financial outcomes. For example, Du, Zeng, and Chang (2018) find that family firm internationalization promotes corporate philanthropy, and that a CEO's political participation reinforces this effect. Heileman and Pett (2018) show that internationally active family firms are more likely than domestic family firms to pass ownership to the next generation of family members. In linking international performance to family firms' international strategic objectives and internationalization motives (Verbeke \& Brugman, 2009; Verbeke \& Forootan, 2012), scholars can improve the quality and precision of family firm internationalization studies.

In conclusion, the study of family firm internationalization outcomes remains one of the most divisive themes in the field. While some scholars attempt to establish a relationship between internationalization levels and financial performance, others, mainly IB scholars, argue that there is no generalized relationship between internationalization and financial performance in family firms. Importantly, non-financial outcomes of internationalization - specifically those related to family firms' noneconomic goals - remain relatively unexplored.

\section{ASSESSMENT AND DIRECTIONS FOR FUTURE RESEARCH}

As is already evident from this review, family firm internationalization is highly contested territory, one where scholars have energetically explored theory, tested a variety of questions, and uncovered a breadth of intriguing and yet largely unreconciled findings. The field is thus ripe for further development - and in particular need of theory that may help reconcile earlier findings. To that end, we structured this review around themes that play a central role in the IB literature, which we hope will make this body of work more accessible and relevant to the IB scholar. This review, therefore, differs from extant reviews of this literature because we draw equally on the family internationalization and IB literatures to identify areas that may prove especially fruitful for future research. These include adopting canonical IB theoretical frames when studying family firm internationalization, adopting an original multilevel perspective from IB that allows us to shift the level of analysis from the firm to the individual, family, and macro levels, paying greater attention to temporal perspectives, improving our methodological toolkit, and exploring IB-related phenomena that family scholars have overlooked. These approaches, detailed in the following sections, should help both IB and family business scholars address the inconsistencies in the current literature, and further our knowledge and theory on new IB topics.

\section{International Business Theoretical Approaches And Family Firm Internationalization}

As we have seen, a wide breadth of theories has been employed in the study of family firm internationalization. These include general theories like agency theory, RBV, resource dependency theory, social capital, stewardship theory, and TCE, and family business-centric perspectives like SEW and bifurcation bias. Yet, less than $20 \%$ of reviewed studies drew on IB theory to inform their analyses. ${ }^{8}$ Relevant disciplinary theories, including internalization theory, the Uppsala model, the OwnershipLocation-Internalization (OLI) paradigm, and international entrepreneurship perspectives, were rarely used as a conceptual lens, and only $36 \%$ of the reviewed studies were published in IB journals. The neglect of IB theory is a missed opportunity. IB research has developed rich and eclectic theory that reflects the essence of governing international transactions. We need a more consistent use of a 
broad, IB-focused theoretical framework in order to accurately explain and predict family firm internationalization and reconcile the mixed findings produced so far.

The notion that firms can create value in crossborder operations by effectively and efficiently matching core firm-specific advantages (FSAs) with the advantages, opportunities, and challenges of foreign locations lies at the heart of IB theory (Verbeke, 2013). To create value this way, firms must overcome the liability of foreignness (Johanson \& Vahlne, 1977, 2009; Zaheer, 1995), or the added costs created by cultural, institutional, geographic, and economic distance between home and host countries (Ghemawat, 2003a). Classic IB theory studies how firms achieve internationalization objectives in the face of these market imperfections, and links value creation in international markets to a number of core concepts, namely, motivation for internationalization, foreign location choice, entry mode choice, entrepreneurial resource orchestration, knowledge transfer, management of a multinational network, and timing of internationalization (Verbeke, 2013). In other words, a variety of IB theories, including internalization theory, an internationally focused version of TCE, the Uppsala model, the OLI paradigm, the knowledge-based view of the MNE (Kogut \& Zander, 1992), evolutionary theory of the MNE (Cantwell, 1989), springboard perspective (Luo \& Tung, 2018), and the network view of the MNE (Forsgren, 2017) provide precise analytical lenses for studying the 'what, where, and how' (Dunning, 1993; Dunning \& Kundu, 1995) of family firm internationalization. Limited integration of IB theories into family firm internationalization research, as found in our review of extant literature, presents barriers for advancing this field of study.

Some have suggested that economic-based IB theory is limited in explaining unique motivations, behaviors, and tensions of internationalizing family firms. Specifically, scholars have argued that IB theory does not account for conflicts within familybased management and ownership groups (Reuber, 2016), does not sufficiently address behavioral aspects relevant for international strategy (Pukall \& Calabrò, 2014), and has limited applicability to situations in which non-economic motives drive international strategy (Rugman, 1981). Therefore, we argue that family firm internationalization is best understood at the intersection of IB, family business-centric, and general theoretical perspectives (De Massis et al., 2018). A simplified integrative model of family firm internationalization rooted in IB theory is presented in Figure 1. The framework is inspired by IB research (Benito et al., 2009; Verbeke \& Kano, 2016) but also draws upon relevant complementary perspectives identified through our review, in order to paint a comprehensive picture of family firm internationalization.

The starting point of our analysis is the firm's resource reservoir (Figure 1, Box 1). From the IB perspective, value creation in international markets depends on the firm's ability to transfer its FSAs to host markets, develop new FSAs in host markets, and recombine extant and new FSAs in novel ways. Thus, whether FSAs are location-bound (LB - nontransferable) and non-location-bound (NLB - transferable) matters. Here, the family firm literature suggests some barriers to FSA development and transfer in family firms may be idiosyncratic; e.g., SEW and bifurcation bias may constrict the transfer of FSAs. Thus, the family business literature highlights how the unique resource endowment of family firms, as well as their idiosyncratic resource gaps and family-influenced strategic logic (Graves $\&$ Thomas, 2008), shape their conduct.

Motivations for international expansion and, consequently, FSA transfer (Figure 1, Box 2) are also best understood from a multidisciplinary vantage point. IB theory explains the economic value proposition of foreign expansion - that is, the nature of advantages sought in foreign locations relative to the home country, such as resource-, market-, strategic asset-, and efficiency-based advantages (Dunning, 1993). In family firms, these 'traditional' motives for internationalization are often supplemented by family-centric, non-economic motives, such as quality of life issues, dynastic aspirations, reputation enhancement, and the establishment of a family legacy (Berrone, Cruz, \& Gómez-Mejía, 2012; Hennart et al., 2019; Kano \& Verbeke, 2018).

Concentration of control in family firms (Morck, Wolfenzon, \& Yeung, 2005) allows the family to act on its noneconomic preferences, thus influencing the specific international governance decisions and processes presented in Box 3 of Figure 1. Decisions and processes that may differ in family firms include location and entry mode choices, partner selection strategies in cases of cooperative entry, and the use of family social capital to facilitate and safeguard foreign transactions. The rhythm and speed of family firm internationalization also differ because of the temporal orientation of family firms 


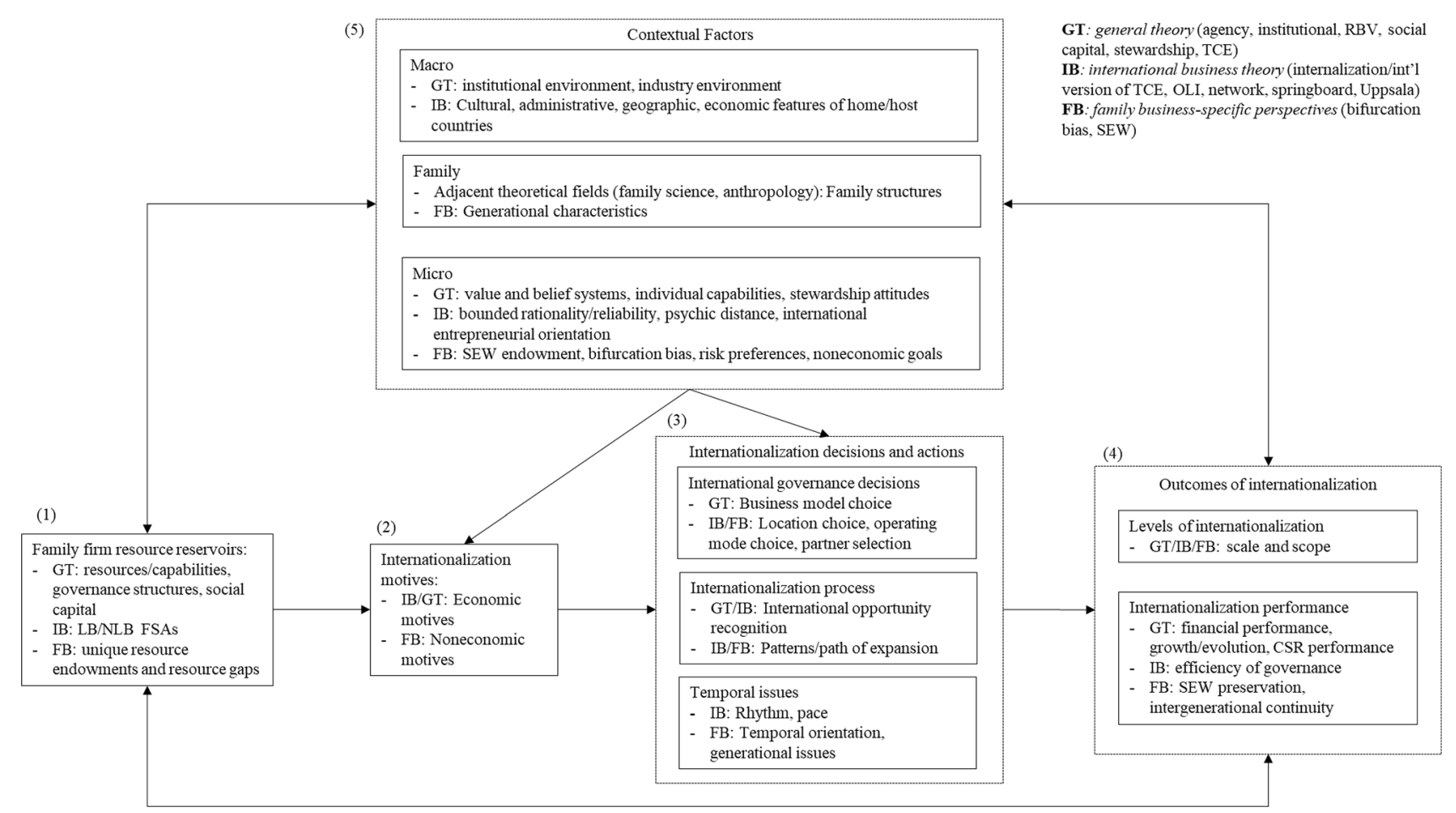

Figure 1 Theoretical treatment of family firm internationalization.

(Miller \& Le Breton-Miller, 2005) and issues related to generational succession. Here, IB-specific theoretical approaches such as, inter alia, internalization theory, OLI, the Uppsala model, the network theory, and the springboard perspective, are particularly useful for examining such decisions and processes.

IB theory provides specific tools that allow researchers to accurately link the complexities of internationalization to the idiosyncratic characteristics of family firms. For example, most family business scholars studying family firm internationalization implicitly assume that internationalization is a homogeneous phenomenon involving significant but predictable risks. Yet IB theory clearly shows that international operations can take many forms, each with a different risk profile. For example, and as discussed above, when foreign sales are realized without FDI by exporting (as is the case in many of the samples analyzed in our literature review), family firms can benefit from their unique resource reservoirs to develop a highquality global niche strategy for exporting with relatively little risk (Hennart et al., 2019). ${ }^{9}$ IB theory thus provides an important baseline for contextualizing family firm internationalization. Family firm-specific perspectives, in turn, help explain why family firm internationalization behavior may deviate from patterns predicted by efficiency-based IB theory.

IB theory suggests that, over time, competition will eliminate inefficient international governance practices, such as those based on affective or biased decision-making (Verbeke et al., 2020). Yet decision-making in family firms is strongly shaped by affective factors, and/or by the family firms' unique goals (e.g., those related to SEW preservation). IB theory is uniquely equipped to predict whether international strategy configurations shaped by such factors are likely to result in value creation and growth in international markets, and whether these configurations are sustainable over time. Internationalization outcomes (Figure 1, Box 4) ultimately lead to a feedback loop to the family firm's resource reservoir (Verbeke \& Kano, 2016), whereby the firm's FSAs are adjusted and augmented based on the firm's past experience and current operations (Benito et al., 2009; Johanson \& Vahlne, 1977, 2009). IB thus offers insights into the dynamic process of internationalization and firm growth, as opposed to the more static perspective of family-centric research.

The firm is affected by, and in turn can affect, its macro and micro-level contextual factors through 


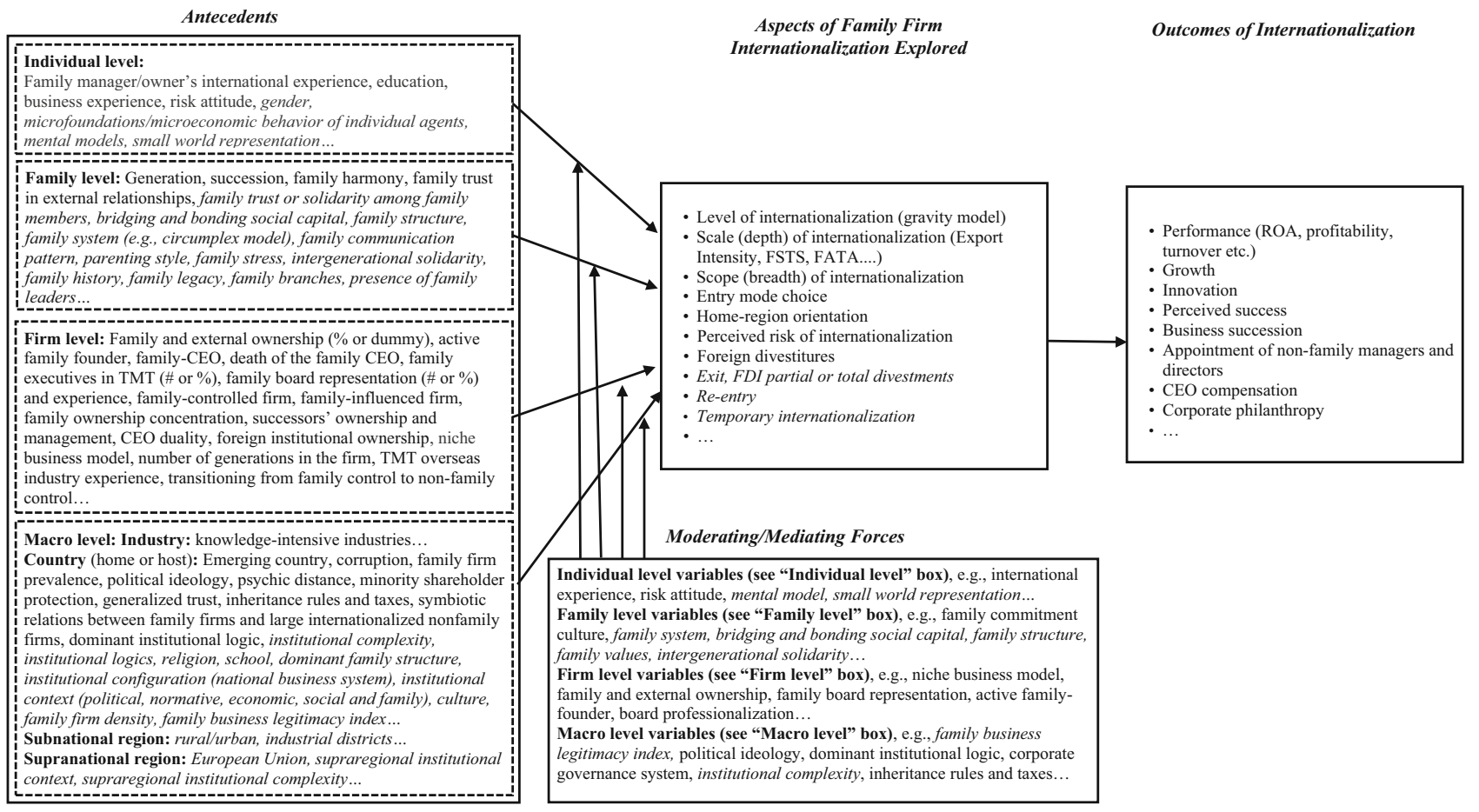

Italic: variables for future research

Figure 2 Levels of analysis in family firm internationalization studies: extant literature and future research.

changes in governance (Williamson, 1996), as shown in Box 5 of Figure 1. Institutional theory highlights relevant macro-level features of institutional environments of home and host countries. IB theory extends these insights by examining the multiple effects of distance between home and host countries on international configurations. IB theory traditionally pays less attention to micro (individual-level) variables of family firm international strategies (Kano \& Verbeke, 2018), with some exceptions (e.g., behavioral assumptions of bounded rationality and reliability). Here, family business research adds insight by highlighting how variables like family objectives, aspirations, and biases, drive decision-making vis-à-vis internationalization. Moreover, deeper understanding of unique family-level contextual characteristics can be obtained by using complementary perspectives from adjacent theoretical fields, such as anthropology and family science (Arregle et al., 2019).

To summarize, we argue that family firm internationalization is best understood from an IB perspective, infused by insights from the family firm literature as well as general management theory, as outlined in Figure 1. IB theory provides an analytical thread to connect various relevant constructs so as to explain the internationalization process in its entirety. Failure to engage IB theory in family firm internationalization studies is one of the reasons for the field's fragmentation.

\section{Levels of Analysis in Family Firms' Internationalization Research: An Imbalanced Literature}

IB research has an inherent multilevel structure, one that becomes even more pronounced in studies of family firm internationalization due to the addition of the family as a level of analysis. As a result, we propose four potential levels of analysis (individual, family, firm, and macro) that can influence family firms' internationalization. Figure 2 visually presents our new framework, which integrates these four levels of analysis with variables considered in existing studies and with variables that we believe future studies should explore (in italics). As detailed below, several key insights can be deduced from Figure 2 .

In terms of levels of analysis, the extant family firm internationalization literature is strongly unbalanced, focusing overwhelmingly on the firm level (97\% of existing studies). Although some studies include other levels of analysis, such as the 
individual level (12\%), family level (22\%), and macro level (20\%), cross-level influences remain under-researched. Accordingly, we focus on the individual, family, and macro levels, which present significant potential for future research.

\section{Individual level}

As compared to other IB studies, family firm-centric studies tend to place greater focus on behavioral aspects. However, most family firm internationalization studies take for granted individual behavioral aspects that shape decision-making, such as family-centric, affect-based, and/or emotional factors. Indeed, quantitative studies using archival data often assume but rarely measure behavioral characteristics like stewardship, altruism, and risk or loss aversion. Tsang (2006: 999) labels this practice "assumption-omitted testing" and argues that such treatment of behavioral assumptions leads to unconvincing and contradictory empirical results in theory-testing studies. For example, multiple authors report that family involvement in ownership and/or management lessens internationalization due to the family's desire to avoid SEW dissipation (Bannò \& Trento, 2016; Dou et al., 2019; Gómez-Mejía et al., 2010; Ray et al., 2018). Wei and Tsao (2019), in contrast, argue that, due to a family firm's long-term orientation, many view internationalization as an attractive investment that can generate future value and increase SEW over time (Xu et al., 2020a). Similar contradictions appear in entry mode studies that build on SEW, as discussed above. Yet, as Schulze and Kellermanns (2015: 454) explain, researchers have relied mainly on family ownership and family management (both firm-level constructs) as proxy measures of SEW, the dimensions of which "have remained largely undefined and unmeasured." In some cases, even firms with the same level of family ownership and management are thought to have different levels of SEW due to differing family preferences, structures, values, and histories. Although SEW is generally viewed as a firm-level construct, its roots reside in family members' attitudes, cognition, and behaviors. Therefore, the microfoundations of SEW should not be ignored in firm-level studies. This contention is supported by Jiang et al. (2018), who find that most SEW research has overlooked the micro-level mechanisms behind the cause-andeffect relationships of SEW.

Further, even when explicated, micro-level theoretical assumptions lack consistency across studies conducted from different theoretical perspectives.
For example, agency, and especially game theoretic, approaches assume full rationality, while TCE assumes bounded rationality. The SEW perspective, in contrast, assumes that affect strongly shapes family firms' conduct, causing them at times to adopt strategies that deviate from 'rational' profit maximization objectives. These divergent behavioral assumptions thus yield conflicting conclusions. However, with some exceptions such as Banalieva and Eddleston (2011) and Holt (2012), the family firm internationalization literature has seen few attempts to reconcile them.

As such, while a rough consensus holds that individuals in family firms can deviate from profit maximization behavior for internationalization and are subject to affective motivations and decision drivers (e.g., SEW, bifurcation bias), no agreement exists on what these motivations are, when they prevail, and how exactly these individual motivations maximize family utility. Consequently, the specific manifestations of relevant actors' affective preferences in firms' international strategy, and how they influence existing IB theories' mechanisms, remain unclear. We argue that the weak theoretical and empirical microfoundations - a weakness also partially recognized in the family business literature (De Massis \& Foss, 2018) prevent scholars from painting a comprehensive picture of family firm internationalization, and, more generally, from leveraging the specificities of family firms to further our knowledge on behavioral components of internationalization. However, this theoretical and empirical gap opens the door to a series of intriguing research questions, including: what kind of parsimonious behavioral assumptions can present a theoretical baseline to explain the behavior of both family and nonfamily actors in family firms? How does this behavior affect internationalization?

Additional theoretical insight is needed to further our understanding about how other factors shape individuals' decisions about family firms' internationalization. For example, Xu et al. (2020a) drew on behavioral theory of the firm and found that the role of SEW in family firms' internationalization scale and scope is shaped by firm performance: when financial performance falls below their aspiration level, family firms are willing to enter more foreign markets (that is, increase scope) despite the potential loss of SEW. Holt (2012) uses image theory to identify conditions under which external actors are able to influence scale and scope of family firm internationalization. Behavioral 
strategy research thus enriches our understanding of the internationalization behavior of family firms. Cognitive perspectives lend added insight. They suggest that individual decision-makers' mental models (i.e., an individual's cognitive structures and processes used to make sense of the world) or small-world representations (i.e., lower dimensional sketches of a situation that an individual believes has the salient characteristics for an appropriate decision) are helpful to delve into the complex mechanisms of internationalization decisions (see Maitland \& Sammartino, 2015). We do not know, for example, whether or how the family context shapes family managers' mental models (e.g., different richness or connectedness) and their internationalization decisions.

Behavioral economics, based on the seminal works of Tversky and Kahneman (1974) and Kahneman (2003), offers useful conceptual and methodological tools for studying how economic agents in family firms make judgments and decisions related to internationalizations. Behavioral economics holds that decision-makers often depart from the rational profit-maximizing behavior - an assumption also shared by family firm scholars. In particular, when managers make decisions within the frame of a family context, the valuation of the potential gains and losses is clearly affected by family aspects. Nepotism (as one expression of bifurcation bias) is a classic example of a biased decision in hiring, at odds with rational economic logic. Further, while many assume that family firms prioritize family interests, e.g., by hiring predominantly family managers (with the exception of a study by Burkart, Panunzi, and Shleifer, 2003), questions concerning the conditions in which an economic logic may prevail over a family logic have been neglected. Experimental methods are promising for investigating this issue in the domain of family firm internationalization. Generally, more research is needed to investigate and test how, why, and when family firms' owners and managers deviate (or not) from the bounds of rationality of economic agents (Hoskisson et al., 2017). In this vein, family firm internationalization scholars could reconcile presently contrasting and/or overlapping assumptions about the (rational or irrational) behavior of actors in family firms: for example, under what circumstances are family owners and managers likely to engage in stewardship versus agency behavior, and how do these choices affect internationalization? How are predictions of IB theories, such as internalization theory or the Uppsala model, affected by family firm-specific theoretical constructs such as bifurcation bias and the pursuit of SEW? Does SEW exacerbate bounded rationality and bounded reliability in host markets (and thus represent a family firm-specific barrier to successful internationalization), or can it safeguard against these challenges? Do family members perceive the costs and benefits of internalization decisions differently due to their bifurcation bias or socioemotional endowment?

Such endeavors would require researchers to disentangle the individual-level factors of family owners and managers that underlie the SEW construct, and to explore how other behavioral concepts (e.g., family owners' or managers' psychological characteristics, biases, heuristics, mental models, small world representation, norms, and values related to their family context) help explain internationalization decisions. Therefore, scholars should engage in rigorous testing of behavioral assumptions relevant to our research agenda; doing so will allow the field to move from assumption-omitted to assumption-based theory testing (Tsang, 2006) and consequently improve the quality and precision of theoretical predictions regarding family firm internationalization. Testing behavioral assumptions, however, requires openmindedness with methodological tools, as we discuss in subsequent sections.

Overall, paying greater attention to the microfoundations of family firms' international strategy will help scholars achieve a deeper understanding of the sources of heterogeneity in family firms, and ultimately reconcile the constraining and facilitating perspectives discussed above. Accordingly, individual-level variables should be added in future family firm internationalization studies (e.g., gender; see Figure 2). Importantly, when developed and tested, these microfoundations can be invoked in research beyond family firm internationalization and incorporated into broader IB studies. As such, IB scholars have an opportunity to leverage family business internationalization studies to further develop the theoretical microfoundations of IB.

\section{Family level}

Despite the central role played by the family itself in family firms' internationalization, few studies target the family level, a trend especially pronounced in the empirical literature. Several studies examine generation as a family-level variable (for example, examining the probability and patterns of internationalization in firms led by first versus 
subsequent generations). However, our review identifies an urgent need to pay greater attention to the family component of family business. Diverse types of families influence family firms' management and strategies differently (Aldrich \& Cliff, 2003). Family heterogeneity should therefore become a key conceptual and empirical component of family firm internationalization analysis (Jaskiewicz \& Dyer, 2017). To accomplish that, IB scholars may turn to adjacent research fields, such as family science and social anthropology, which provide a fine-grained analysis of families and their heterogeneity. Jaskiewicz, Combs, Shanine, and Kacmar (2017) propose that we should tap into the rich descriptions of families in family science research and present family science theories relevant to the study of family firm internationalization, like family systems theory (e.g., the circumplex model; Olson, 1986, 2000), family communication patterns theory, family-niche model of birth order and personality, parental control theory, family development theory, $\mathrm{ABCX}$ model of family stress, and intergenerational solidarity theory.

Social anthropology offers another illuminating perspective on family heterogeneity. A long tradition of research in social anthropology has investigated how structural dimensions of families explain differences in beliefs or values of individuals. Arregle et al. (2019) demonstrate how insights on family structures, developed within the social anthropology field, can help link family heterogeneity and family firm internationalization. The authors use Todd's (1985) typology of family structures to show how families' diverse values form the core of family firm management and can shape international strategies. Future studies could investigate relationships between family structures and different aspects of internationalization. For instance, do family firms with a specific family structure have a higher level of internationalization? How does family structure influence a family firm's international modes of entry? Do family firms prefer to find international partners with a similar family structure? Is there a family structure that leads to inferior or superior family firm internationalization performance?

Finally, with the exception of papers published in specialized journals such as Business History (e.g., Amatori, 2016; Castagnoli, 2014; Colli, GarciaCanal, \& Guillén, 2013; Fernández-Moya, 2010), few studies investigate the influence of family history on internationalization. However, family history provides an additional rich source for understanding a family firm's international paths and strategies, particularly in the case of longstanding, multigenerational family MNEs, where the strategic imprint of past generations continues to prevail across multiple successions (Jaskiewicz, Combs, \& Rau, 2015). Here again, an interdisciplinary approach may prove fruitful: family firm and IB scholars can engage with business history research in order to incorporate historical methods into the study of family firm internationalization, in line with IB scholars' recent calls for using history to advance IB theory (Buckley, 2016).

\section{Macro level}

A number of studies examine macro-level characteristics of the firm's host and home environments to reconcile the mixed results on family firm internationalization (Arregle et al., 2017; De Massis et al., 2018). Institutional context - a country's set of political, normative, economic, and social institutions - has garnered the most scholarly attention, with institutional economics theory (North, 1990) serving as the primary conceptual lens. The effects of formal (e.g., minority shareholders protection, inheritance rules, and taxes) and informal (e.g., generalized trust, political ideology) national institutions on family firm internationalization have been proposed and measured, as discussed above. However, we see many opportunities to further develop this perspective by examining other formal and informal, home or host country institutions such as property rights and intellectual property protection, legal systems, employment laws, and banking, as well as informal systems such as trading favors, clans, and diasporas. The legitimacy of family firms (Berrone, Duran, Gómez-Mejía, Heugens, Kostova, \& van Essen, 2020) in a home or host country may be key to studying family firm internationalization. ${ }^{10}$ The configurations of institutions, such as the concept of national business system (Redding, 2005; Whitley, 1992) or comparative capitalisms (Jackson \& Deeg, 2008), is also a promising way to explain family firms' internationalization from a macro-institutional perspective.

Curiously, the concept of institutional logics, which are "assumptions and values, usually implicit, about how to interpret organizational reality, what constitutes appropriate behavior, and how to 
succeed" (Thornton, 2004: 70), has been overlooked in family firm internationalization research (Luo et al., 2009 is an exception). Institutional logics can guide and constrain family firms' decision makers. The relationship between internationalization decisions and the logics that constitute the firm's institutional context is important to understanding how and why family firms exhibit similarities and variation in their internationalization. A key difference between this approach and conventional country-level institutional analysis is its acknowledgement that organizational fields are usually characterized by institutional complexity: they have multiple, and often conflicting, logics (Greenwood, Diaz, Li, \& Lorente, 2010). Even if a dominant logic can exist (e.g., the logic of the market), less prevalent logics may exert a localized or weak influence, such as logics specific to a family (Greenwood et al., 2010). The family is a central background institution (Arregle et al., 2019) ${ }^{11}$ and can have logics that vary, for example, across family structures (Todd, 1985). A family firm where the family logic pervades may make internalization choices that differ from those of a family firm where a market logic prevails, even if both are from the same country and have the same level of family ownership and management. Comparing family to non-family firms can also illuminate how internationalization levels are affected by different institutional logics. More specifically, future research might explicate how family firms uniquely confront and navigate institutional complexity in their internationalization choices. Broader IB studies can also benefit from these different analyses to advance and refine their institutional perspective.

Beyond institutions, other relevant constructs include cultural, economic, and spatial (geographic) characteristics of the macro-environment. Culture is sometimes equated with informal institutions and subsumed under the macro-institutional banner. It is noteworthy that neither culture nor institutions is uniquely confined to the country level: relevant institutions can be more local or more global. For example, they can be subnational, as a country is rarely a homogeneous entity and often has many regional cultures (e.g., Dheer, Lenartowicz, and Peterson (2015) identified nine distinct cultural regions in India). Indeed, withincountry diversity is often as large as the variation of culture across countries (Au, 2000; Fischer \& Schwartz, 2011; Peterson, Søndergaard, \& Kara, 2018). Uniquely related to the family level, a subnational region can experience a dominant family structure that differs from another region in the same country. For instance, France has four dominant family structures across its geographic regions (exogamous community, authoritarian, egalitarian nuclear, and absolute nuclear (Todd, 2011)), with enduring effects on regional disparities. Hence, a family firm in a particular subnational region can develop different international processes and outcomes compared to another family firm located in the same country but in another subnational region with different institutional features.

The urban versus rural dynamic (Tunberg, 2014) is another macro-level dimension highly relevant for family firms. Baù, Chirico, Pittino, Backman, and Klaesson (2019) find that Swedish family firms benefit from a rural setting, where it is easier to form alliances and build close connections with the community compared to urban areas. Moreover, levels of economic activity, development, and resources are unevenly distributed across space, with some regions enjoying an abundance of resources while others suffer from scarcity. Given that family firms tend to build stronger and more durable relationships with stakeholders within their local context (Baù et al., 2019), spatial distinctions are relevant to the study of internationalization. In this respect, an interesting research question would be to examine the extent to which regional rural and urban contexts drive family firm internationalization strategies, and whether family firms in the same context (either rural or urban) undergo similar internationalization processes, thus introducing the overlooked urbanrural dynamic to IB.

Another unexplored but promising avenue is the role of industrial districts in family firms' internationalization. Industrial districts are territorial entities characterized by specialized local knowledge, industry concentration, and strong social interactions (Cucculelli \& Storai, 2015). An industrial cluster location benefits family firms. For instance, Naldi, Cennamo, Corbetta, and Gómez-Mejía (2013) find that family CEOs achieve higher family firm financial performance in industrial districts, where social norms and tacit rules are prominent, than in contexts like stock exchange markets, where formal constraints and requirements are more important. However, the impact of industrial districts on family firm internationalization remains unexplored. Future studies can investigate 
their role in sustaining active internationalization by local family firms as well as their role in attracting investments by foreign family firms.

Supranational regions also matter. Institutions often have a supranational regional dimension, as explored in the regionalization and semi-globalization literature (Ghemawat, 2003a; Rugman \& Verbeke, 2004). For instance, a supranational region's institutional complexity influences MNEs' location choices (Arregle, Miller, Hitt, \& Beamish, 2016), but we do not know if family MNEs react differently to this institutional complexity. The institutional characteristics of a supranational geographic region - such as the European Union - can also uniquely influence family firms' internationalization, but regional effects have not been widely examined (Banalieva \& Eddleston, 2011 offer an exception). Future studies can examine the relationship between various aspects of supranational regions and family firms' internationalization.

Future work might also study the effect of such macro-variables as family firm density or prevalence (the number or percentage of family firms in a country or region, Berrone et al., 2020) on family firms' propensity to internationalize. Family firms are often depicted as organizational systems in which reciprocity, altruism, long-term commitments, and collective benefits assume paramount roles. Through informal interfirm interactions, these values tend to be disseminated in local communities, thus creating an environment that facilitates the use and exchange of resources with the external network of local stakeholders (e.g., local suppliers and customers, actors in the labor market) (Baù et al., 2019; Bird \& Wennberg, 2014; Chirico, Ireland, \& Sirmon, 2011; Miller \& Le Breton-Miller, 2005). Future studies may explore whether increased family firm density in a given location (either the home or host region/country) creates favorable conditions for family firms' internationalization.

Industry represents another relevant level of analysis. Industries can have their own institutional logics and influence on family firm internationalization, which suggests paths for future research avenues. For instance, knowledge-intensive industries (e.g., high-technology), which are based on intensive use of technology and/or human capital, may affect family firm internationalization dynamics differently, given the complex relationships between $R \& D$ investments and family firms (Gómez-Mejía, Campbell, Martin, Hoskisson, Makri, \& Sirmon, 2014).

\section{Cross-level influences}

The four levels of analysis we propose in Figure 2 bring together complementary perspectives and theories to explain family firm internationalization. We have highlighted knowledge gaps and potential future research topics at different levels. In addition, a deeper understanding of the crosslevel effects can help reveal how characteristics at various levels impact specific outcomes of family firm internationalization (Eddleston, Jaskiewicz, \& Wright, 2020), in terms of internationalization levels, geographic configurations, operating mode bundles, speed and rhythm of internationalization, or international performance. More precise research questions would help reconcile the previous inconsistent empirical results on the family firm internationalization process.

We see two main potential paths forward. The first is to study the cross-level relationships among these levels of analysis. Variables at the different levels of analysis listed in Figure 2 have the potential to be moderators. For instance, the effects of macro-level characteristics, such as institutions, can moderate the relationship between a family firm's characteristics, such as family control, and internationalization. Arregle et al. (2017), Duran et al. (2017), and Eddleston et al. (2019) are examples of studies in which institutional variables moderate the relationships between firm-level variables and internationalization variables. Mediating effects are rarely studied in family firm internationalization (see Appendix 1), yet they are relevant, especially for the study of international performance. Here, for instance, the characteristics of individuals, families, family firms, and/or countries influence international strategic decisions, which, in turn, result in international success or failure. ${ }^{12}$ The second path is to consider configurations of variables at different levels of analysis. A configuration approach, inspired by research on national and regional business systems or comparative capitalism, could be used to relate configurations of variables at different levels to explain family firm internationalization and performance.

These approaches underscore the notion that cross-theory integration across levels of analysis will promote important multilevel theories and models in family firm internationalization research. The application of individual-level theories in conjunction with family, firm, and macrolevel theories has barely been utilized to study family firm internationalization conceptually or empirically. Multilevel models are the natural 
method to achieve this result, but qualitative studies and fuzzy-set methods may also advance our knowledge of these multilevel phenomena.

\section{Temporal Perspectives}

Relationships in Figure 2 highlight the importance of the temporal perspective in studying family firm internationalization. Each of the four conceptual levels (individual, family, firm, and macro) has its own temporal dynamic, which raises the possibility of potential reverse effects between antecedents and aspects, or outcomes, of internationalization (De Massis et al., 2018). Much depends on the research time horizon. A cross-sectional study or a study encompassing a relatively short time span (e.g., 5-10 years) could potentially consider a directional effect from antecedents to aspects/outcomes of internationalization. Yet a longitudinal study spanning, e.g., 30 years could also take into account how a family firm's past internationalization (i.e., aspects or outcomes) influenced individual- or family-level variables that, in turn, would help explain current internationalization. For example, a family's tradition or legacy could result from the past successes or failures in a firm's internationalization history, as touched upon in the review section. International education of family executives could be influenced by the family firm's past international footprint. In extreme cases, family firm internationalization could even influence macro-level variables, e.g., when large powerful family firms are able to influence some local or national institutional rules or cultural norms (Soleimanof et al., 2018). Therefore, the relationships among variables might require more elaborate modeling. Process-focused, long-term qualitative studies could help us understand dynamic multidirectional interactions between family firms, their environments, and their internationalization outcomes presented in Figure 2.

Some scholars have striven to understand family firm internationalization strategies over time (Scholes et al., 2016; Stieg et al., 2018). Interestingly, these studies deliver results at odds with papers that do not consider the time perspective of family firm internationalization. For example, in their study on entry mode choices, $\mathrm{Xu}$ et al. (2020b) find that, in the first stage of internationalization decisionmaking, family ownership increases the likelihood of a JV versus WOS, but that, in the second stage, family ownership in family-influenced firms increases the likelihood of choosing WOS via an acquisition (versus a greenfield investment).
Overall, studies that do not consider the passage of time generally predict that family firms have a greater propensity toward greenfield initiatives over acquisitions (e.g., Boellis et al., 2016; Yamanoi \& Asaba, 2018). We agree with Yang, Li, Stanley, Kellermanns, and Li (2018: 425) that decision dynamics in family firms are different at different stages of internationalization, i.e., "when the family firm makes the decision to initiate exports compared to the decision to increase exports." Incorporating a time dimension while relying on theoretical frameworks that allow the researcher to make time-related predictions (e.g., mixed gamble model, real-option theory; see, e.g., Hoskisson et al., 2017; McGrath, 1999) has the potential to offer deep insights into the complex family firm internationalization process.

\section{Methodological Opportunities}

Our analysis of the literature suggests that new empirical approaches, along with elaboration of current methods, will further knowledge. We identify two main areas for improvement.

\section{Definition and measurement}

As aforementioned, definitions of family firms vary in studies on internationalization. They include different components and levels of family involvement as contingency factors (Chrisman, Chua \& Sharma, 2005), explaining the different results of studies on family firm internationalization (Arregle et al., 2017). However, given the complex nature of the family's influence on the firm's international strategy, a definition that encompasses both family ownership and family management is probably the most relevant to study internationalization. Family involvement in both ownership and management means that the family can in fact act on its familycentered objectives and thus trigger specific internationalization paths (Arregle et al., 2017; Hennart et al., 2019). For instance, in order for the negative effects of family social capital on a firm's managerial diversity and international scope to materialize, significant family involvement in the ownership and management of the firm is required. Similarly, family members must be involved in both ownership and management to be able to promote their SEW preferences or exercise stewardship.

However, the levels of family ownership and managerial oversight also matter. It turns out that family-controlled firms (i.e., those with unilateral family control) suffer more from negative impacts of family on internationalization, as compared to 
family-influenced firms (e.g., Arregle et al., 2017; D'Angelo et al., 2016). However, family-controlled firms are probably the more interesting context for IB research: In this case, the distinctive aspects of family firms' internationalization are particularly evident, helping to advance IB knowledge on noneconomic dimensions in internationalization decisions.

This example of definition-influenced outcomes illustrates a common problem in family firm internationalization research: the weak link between a study's theoretical scaffolding and its definition of family firms. Rather than trying to establish a definition of family firms that is universally applicable to studying internationalization, it is paramount to choose the right definition for each particular study. The problem is that in many of the reviewed studies, family firm definitions do not necessarily map tightly to the theories or organizational attributes being studied, which confounds empirical results and inference. ${ }^{13}$ For instance, a study arguing that family firms' stewardship explains their internationalization needs to define family firms in a way consistent with the central theoretical construct: that is, the definition must allow for influence of stewardship on firm conduct (e.g., through the substantial presence of family members in ownership and management). In this case, defining family firms based solely on ownership (as is often the case in IB studies) seems inconsistent with the theoretical requirements of the study (Zahra's (2003) above-mentioned nuanced exploration of international scope of family firms illustrates this point). Additionally, such a study would need to rely on a sample of firms with different levels of family ownership and management and employ measures that reflect those differences. However, if the theoretical question concerns the effects of distinctive principalprincipal agency conflicts in family firms' internationalization, using an ownership-based (rather than an ownership- and management-based) definition would be acceptable.

In terms of studies adopting an SEW framework, it remains unclear which family firm definition is best. Indeed, SEW is rooted in behavioral agency models that were developed to explore top management team compensation. Yet, SEW-based studies of family firm internationalization assume that the effects of SEW manifest whenever family members influence decision-making - not merely when they are members of the top management team - and use multiple definitions of family firms.
As such, they do not take into account whether or how the effects of SEW may differ across forms of family ownership (e.g., ownership versus control) or across varying board compositions or management structures (e.g., family versus non-family CEO). Stronger theoretical linkages between the SEW construct and family firm definition are needed in order to advance such research.

Another empirical challenge is the operationalization of family firm definitions. What constitutes a 'significant' level of family ownership or management has been operationalized differently depending on the type of firm (private or public) and home country. Usually, $50 \%$ of ownership is required for a private firm to classify as a family firm, but this amount can be $5 \%$ or $10 \%$ for public firms (GómezMejía et al., 2010). The same ambiguity surrounds accounting for the presence of family in management and boards, as some studies simply use the presence of family managers and board members as a proxy (yes/no), some use the raw number of family managers and board members (Sirmon et al., 2008), and still others use their percentage in the management team or on the board (Hennart et al., 2019; Majocchi \& Strange, 2012). All of this is made more complex when firms are located in a country where they can issue special shares giving a majority of voting rights to a family with a minority ownership. In these countries, voting rights owned by a family, and not its ownership per se, are the appropriate measure (Sestu \& Majocchi, 2020). Given the cross-country nature of family firm internationalization research, it is difficult to propose the one best way to address these issues. Variation in family firm measurement and definition must be accepted as endemic to this field, but it remains that studies will lack robustness unless researchers clarify the specific links among their theoretical constructs, empirical measures, and research contexts. Finally, using a dichotomous variable of family firms (yes/no) has been useful in past research, but more precise measures of family firms' characteristics (e.g., level of family ownership and voting rights, importance and role of family managers) are needed if we are to advance our knowledge about these firms' international behavior.

Our review shows that the two main internationalization variables best explained in the empirical literature are, by far, the degree (that is, scale and scope) of internationalization and, to a lesser extent, entry modes. However, as aforementioned, most studies use the 'internationalization' label to 
refer to international scale (usually measured as the ratio of foreign sales to total sales). Yet international scale and scope should not be conflated. Some theories that predict a positive relationship between family ownership-management and international scale, such as the social capital perspective, also imply limited (that is, a negative relationship to) international scope. Further, Arregle et al. (2017) found in their meta-analysis that the relationship between family firm and international scale is null, yet the relationship with international scope is negative and statistically significant. Therefore, using precise dependent variables for internationalization ${ }^{14}$ to disentangle its different facets, in accordance with the proposed theoretical mechanisms, is an important operationalization issue ${ }^{15}$ that has significant conceptual consequences for future research.

One of the most striking empirical gaps is the paucity of studies on family firms' FDI. Most studies focus on exporting as the de facto entry mode and measure of internationalization; the all-important FDI phenomenon, along with family MNEs, is relatively overlooked. This oversight might result from the predominance of SME samples, since exporting is SMEs' most common internationalization strategy. It is important that future studies differentiate family firm effects from SME effects, and make sure that our knowledge on family firm internationalization is influenced not by variables or theories related to (non-family) SMEs, but by variables/theories reflecting the uniqueness of family firms, irrespective of size.

As mentioned, more refined measures are needed to capture SEW effects on international strategy of family firms, particularly given the central role of the SEW construct in family firm internationalization studies. For example, accurate reference points for SEW need to be established in order to measure potential losses or gains of this nonfinancial utility. Further, SEW is a multidimensional construct, with various socio-emotional preferences potentially influencing internationalization in distinct ways. Future research should attempt to empirically differentiate between various dimensions of SEW. Recent attempts to measure SEW in the family business literature (e.g., Debicki, Kellermanns, Chrisman, Pearson, \& Spencer, 2016; Hauck, Suess-Reyes, Beck, Prügl, \& Frank, 2016) have produced divergent results. New methods will help to address this issue. Such endeavors can contribute to the broader study of decision-making in IB.

\section{Methods}

As mentioned above, we contend that studying family firm internationalization requires multilevel methods that integrate variables at the individual, family, firm and macro levels. Such analysis offers a more comprehensive view and promises to reconcile the many contradicting results in the field by accounting for the intrinsic heterogeneity of family businesses and their internationalization paths. Fuzzy-set qualitative comparative analysis (fsQCA) could also bring new interesting insights as it can deal with the equifinality that seems to exist when explaining levels of family firm internationalization: if family firms can reach the same level of internationalization than non-family firms, but with different configurations of internationalization properties, equifinality exists. FsQCA enables us to develop or test theories that account for causal complexity, equifinality, and asymmetric causality in explaining family firm internationalization.

As reported by Demsetz and Lehn (1985) and Heugens, van Essen, and van Oosterhout (2009), family firms are not randomly distributed across sectors and countries. This uneven distribution could generate potential endogeneity and sample bias distortion, which, if not properly addressed, could bias results. Endogeneity may also exist if variables explaining the family status of firms affect internationalization (Hennart et al., 2019). For example, family firms sometimes concentrate in industry sectors or countries that, for a variety of reasons, show low levels of internationalization. This implies that family firms' lower degree of exports regularly reported by researchers could be attributed to the industry/country concentration and not to specific family firm characteristics. So far, the number of studies that have addressed endogeneity issues remains extremely low (less than $5 \%$ of the studies in our sample). Further efforts in this direction are clearly needed.

Our review also reveals an urgent need to address the microfoundational basis of the field. This requires empirical methodologies with the capacity to investigate the actual behavior and risk attitude of relevant actors in family firms, such as survey research, experiments, simulations (Felin, Foss, \& Ployhart, 2015; Kano \& Verbeke, 2019), policy capturing, games, text mining, and text analyzing. Such alternative methodologies are rarely used in IB and family business fields, however, they offer a unique opportunity to study family managers' and owners' cognition and motivation, and to develop 
formal normative models of belief and choice that are truly representative of the reality of family business and internationalization decisions.

\section{Other Aspects Of Family Firm Internationalization Research}

Beyond theoretical and methodological opportunities, our review highlighted several under-investigated phenomena that present interesting IB research avenues. First, our analysis revealed a surprising disconnect between the basic theoretical underpinnings of much family firm internationalization research and its conceptualization of international performance outcomes. Although nonfinancial goals are deemed highly relevant for family firms, most empirical studies focus on financial outcomes of internationalization (see Figure 2). We are thus missing the opportunity to investigate whether internationalization leads to important non-economic benefits for stakeholders.

Second, international corporate governance has grown as an IB field over the last decades. Comparative corporate governance is "the study of relationships between parties with a stake in the firm and how their influence on strategic corporate decision making is shaped by institutions in different countries" (Aguilera \& Jackson, 2010: 491). Given that family firms are the most common type of firms throughout the world, understanding how their corporate governance leads to different internationalization decisions across countries is conceptually and empirical important. For example, research about the influence of minority shareholders on family firm internationalization is mixed. Some researchers conclude they are beneficial, but others (e.g., Arregle et al., 2017) suggest that minority shareholders' objectives can dampen family firm internationalization through their focus on strategies that enhance short-term financial performance (e.g., Lazonick \& O'Sullivan, 2000). Theoretical and empirical research is needed to better understand minority shareholder influence on family firm internationalization. Family firms also possess unique characteristics and dynamics related to power and influence over decision-making. These attributes provide family business internationalization scholars an opportunity to distinctively contribute to international corporate governance research. For example, an important issue in international corporate governance is the non-identical nature of actors across different institutional contexts, as actors are embedded within a particular setting that helps define their identities, values, and interests (Aguilera \& Jackson, 2010). Family firm internationalization studies can shed new light on these dynamics, as family owners and managers are two categories of actors who may exhibit unique fundamental differences across countries or regions. As depicted in Figure 2, they can be influenced by a context made of multiple levels of analysis, including the family level. These actors are strongly embedded in a 'thick' institutional context due to the family dimension of the firm. Therefore, research on family firms' internationalization across countries can advance our knowledge of the diversity of corporate governance actors. The variables presented at the family and macro-institutional levels (Figure 2), and their cross-level effects, are potentially the most interesting ones for such endeavor.

Third, extant literature appears silent on the issue of international human resources management (HRM) in family MNEs. Whereas the broader family firm literature pays significant attention to family firm-specific HRM issues such as, inter alia, bifurcation bias (Verbeke \& Kano, 2012), altruism (Schulze et al., 2001), amoral familism (Banfield, 1958), and engagement of nonfamily employees (Neckebrouck et al., 2018; Ramos, Man, Mustafa, \& Ng, 2014), family firm internationalization scholars have yet to engage with these topics. Exploration of international HRM in family firms is potentially significant for both scholars and practitioners, as inherent family firm-specific personnel challenges are further complicated in an international context by such issues as cross-country differences in labor laws, reward and incentive systems, workforce skills and education, as well as by cultural distance. The need to manage the mix of expatriates and local employees present additional difficulties for HRM in family firms. Considering the worldwide prevalence of family firms, this issue has important social implications. This field of research is virtually untapped.

Fourth, it would be useful to further capture family business exit or partial or total divestments of FDI (Chirico et al., 2020; Kim, Hoskisson, \& Zyung, 2019), re-entry (Akhter, Sieger \& Chirico, 2016), and temporary internationalization (i.e., a process going from internationalization, to deinternationalization, to re-internationalization; Kuiken, 2019). Research on exit or de-internationalization is almost absent. To the best of our knowledge, Kim, Hoskisson, and Zyung (2019) is one of the few published articles on international divestment decisions by family firms. The authors 
find a negative relationship between family CEOs and divestment of FDI, and this relationship is amplified for subsidiaries with larger affective endowments. De-internationalization and divestment in family firms presents a fruitful potential research avenue, due particularly to additional family firm-specific considerations related to affect, path dependency, family history or legacy, and bifurcation bias. Future studies can further investigate this promising topic, which is becoming ever more important considering today's environment of skepticism toward globalization and renewed protectionism.

Fifth, the impact of family on international strategy and structure is virtually unresearched. Future studies can explore whether family governance is particularly effective when pursuing a specific international strategy, as described in various IB and/or global strategy frameworks, e.g., integration/responsiveness framework (Prahalad \& Doz, 1987), aggregation/adaptation/arbitrage framework (Ghemawat, 2003b), ${ }^{16}$ or administrative heritage framework (Verbeke, 2013). The family's role in navigating decisions surrounding headquarters and subsidiaries, subsidiary mandate management and resource allocation, and specific ways of organizing the multinational network also warrant further research.

\section{Managerial And Social Impacts Of Family Firm Internationalization}

The various aspects of family firm internationalization presented in this review have important managerial and social implications. From a managerial standpoint, this review has uncovered actionable insights related to key aspects of family firm internationalization, including leveraging family-based resources (e.g., social capital), development and transfer of capabilities, access to complementary resources, business models and strategies ideal for internationalizing family firms, and family structures and intergenerational dynamics, among others. We have also shed light on family firm-specific barriers to successful internationalization, including bifurcation bias, overreliance of existing social capital, intra-family conflict, and excessive focus on SEW. Close attention to these issues can guide family firm owners and managers, as well as family leaders, in improving internationalization outcomes and performance. Moreover, our review provides managers with insights on several dimensions at the family or macro levels that can influence their international strategic actions. At the same time, managers in nonfamily firms could also benefit from these insights by trying to emulate some features of family businesses that promote successful international expansion. Further, macro-level variables discussed in the review - in particular, regulatory issues related to family business management may be of interest to policymakers interested in making country-level institutions family businessfriendly, and in promoting the internationalization of their family firms.

The success or failure of a family firm's internationalization has major implications for a local social context (e.g., a city or region) due to the particularly strong and long-term embeddedness of family firms in their local environments. Hence, when a medium or large family firm's internationalization derails (e.g., The Falck Group in Milan; or ILVA in Taranto - Italy), the implications for the local communities are often drastic (Dunford \& Greco, 2007; Salvato, Chirico, \& Sharma, 2010). Considering the large number of family firms and their structural roles in many economies, a better understanding of their internationalization, and related policies (e.g., environmental), is paramount for the general study of how business impacts society. Future studies aimed at enhancing the managerial and social impacts of family firms' internationalization (successful or unsuccessful) strategies appear very promising.

\section{CONCLUSION}

Extant research has covered much empirical and conceptual ground and improved our understanding of family firm internationalization. In contrast with earlier reviews, ours uses an IB lens to systematize this research, highlights key contributions relevant for IB scholars, and identifies theoretical, empirical, and methodological gaps that should be addressed. Importantly, our analysis suggests that the context of family firm internationalization can contribute valuable insights to the broader IB scholarship. Specifically, greater attention to such conceptual and methodological issues as micro-level affective motivations, background social institutions, temporal perspectives, and multi-level analyses is helpful beyond the realm of family business. Insights presented here can be fruitfully adapted for the study of other forms of international firms. These include firms where noneconomic motivations may factor into international strategy decisions, such as state- 
owned enterprises or not-for-profit organizations, as well as traditional MNEs and international new ventures, which can also be subject to decisionmakers' bounded rationality and reliability (and, as such, biases and decision-making fallacies). Our review shows that different disciplinary fields general management, IB, family business, family science, business history, and anthropology, among others - contribute unique angles to our knowledge of family firm internationalization. We believe that this complex phenomenon is best understood at the intersection of multiple disciplinary and theoretical perspectives. Our proposed future research agenda advocates a cross-disciplinary, multi-theoretic, and cross-level approach to studying family firms and their international strategy. Much work remains in terms of streamlining assumptions, definitions, and measures, and we hope to see more stimulating, theoretically grounded, and methodologically rigorous studies of family firm internationalization in the years to come.

\section{ACKNOWLEDGEMENTS}

We would like to express our sincere gratitude to Prof. Ilan Vertinsky and three anonymous reviewers for their valuable guidance and support. We thank Haskayne School of Business at the University of Calgary for funding the research for this paper through the Transformative Research Grant.

\section{NOTES}

${ }^{1}$ With the exception of Debellis et al.'s (2020a) and Metsola et al.'s (2020), which classified 134 and 172 articles, the scope of these reviews is quite limited, ranging from a low of 25 (Kontinen \& Ojala, 2010) to 115 articles (Alayo et al., 2020).

${ }^{2}$ In 2018, 2019 and 2020, we considered accepted articles published as Early View or Online First articles. For 2020, we searched articles published until December 1st.

${ }^{3}$ We recognize that, as a result of our search strategy, this review includes research published in journals with significant variance in quality standards or impact factors. It is therefore possible that some of the conflicting results highlighted in the review could be attributed to differences in publication standards. However, it is noteworthy that Arregle et al. (2017) found in their meta-analysis that journal impact factors had no statistically significant effects on the family firm-internationalization relationship. Further, at the screening stage, we exclude studies that suffered from fundamental and obvious execution flaws. Finally, when synthetizing findings, we gave greater emphasis to studies published in reputable journals.

${ }^{4}$ We used the following keywords: family control, family ownership, family management, family firm, family business, family MNE, family group, or family SME; and, internationalization, global/ international strategy, $\mathrm{MNE} / \mathrm{MNC}$, international SME, global firm, foreign direct investment, mode of entry/exit, export, scope/scale of internationalization, born global, global/home-region orientation, global value chain, joint venture, wholly owned subsidiary, international alliance, international franchising, or international investment.

${ }^{5}$ To stay consistent with terminology used in most family firm internationalization research, we use an umbrella term 'entry modes' to refer to both initial modes of entry into a host country and subsequent modes of operating in that country, including potential mode changes, adjustment, and bundles (see Benito, Petersen, \& Welch, 2009).

${ }^{6}$ Some studies addressed multiple phenomena; if this was the case, we coded the study according to what we perceived to be its dominant focus, while making sure that we address all relevant findings in our research synthesis.

${ }^{7}$ Bifurcation bias (Kano \& Verbeke, 2018; Verbeke $\&$ Kano, 2012) refers to a dysfunctional decision rule in family firms, whereby family assets are systemically viewed as valuable, and nonfamily assets as short-term and commodity-like, regardless of these assets' actual contribution to value creation in the firm. Both human and non-human assets can be subject to bifurcation bias. Not all family firms are bifurcation-biased, but they are inherently more susceptible to this bias than firms with dispersed ownership.

${ }^{8}$ For simplicity, we included studies conducted from the TCE perspective in this count, as these studies mostly used an internationally focused version of TCE. It should be noted that internalization theory is rooted in the transaction cost economics logic, specifically the work of Coase (1937). Coase's core idea - that a hierarchy supersedes the market when internal organization involves lower costs than market transactions was further developed in two parallel streams of research: Oliver Williamson's foundational TCE work (Williamson, 1975, 1981) and internalization 
theory work by 'Reading School' scholars (Buckley \& Casson, 1976; Rugman, 1981). While these two streams of research share Coasean foundations, they differ in that internalization theory extends the core transaction cost logic to explain crossborder business exchange, while TCE is not concerned specifically with the IB context, and is therefore a general, rather than an IB, theory. Yet, the links between TCE and internalization theory are apparent, and some IB scholars, most notably Jean-Francois Hennart, conduct IB research from a transaction cost perspective. Specifically, Hennart (1982) can be credited for explicitly linking TCE and internalization theory in his dissertation, arriving at an internationally focused version of transaction cost theory that is suitably equipped to explain behavior of MNEs.

${ }^{9}$ We thank an anonymous reviewer for raising this point.

${ }^{10}$ Berrone and colleagues (2020) developed a family business legitimacy index, made of four informal institutions: intergenerational survival orientation, continuity orientation, network-based relations, in-group solidarity, and patriarchal domination.

${ }^{11}$ Background social institutions, such as families, religious organizations, or schools, exert mimetic and normative influences on individuals (Whitley, 1992). They yield implicit, collective knowledge based on shared social values pertaining to "how things ought to be" (Calori, Lubatkin, Very, \& Veiga, 1997; Whitley, 1992).

\section{REFERENCES}

(Papers included in the literature review_see online Appendix 1 - are marked with an asterisk.)

*Abdellatif, M., Amann, B., \& Jaussaud, J. 2010. Family versus nonfamily business: A comparison of international strategies. Journal of Family Business Strategy, 1(2): 108-116.

Aguilera, R. V., \& Jackson, G. 2010. Comparative and international corporate governance. Academy of Management Annals, 4(1): 485-556.

Akhter, N., Sieger, P., \& Chirico, F. 2016. If we can't have it, then no one should: Shutting down versus selling in family business portfolios. Strategic Entrepreneurship Journal, 10(4): 371-394.

Alayo, M., Iturralde, T., Maseda, A., \& Aparicio, G. 2020. Mapping family firm internationalization research: Bibliometric and literature review. Review of Managerial Science.. https:// doi.org/10.1007/s11846-020-00404-1.

*Alayo, M., Maseda, A., Iturralde, T., \& Arzubiaga, U. 2019. Internationalization and entrepreneurial orientation of family SMEs: The influence of the family character. International Business Review, 28(1): 48-59.
${ }^{12}$ See Carney, van Essen, Gedajlovic, and Heugens (2015) and van Essen, Carney, Gedajlovic, and Heugens (2015) for examples explaining family firms' performance.

${ }^{13}$ We thank an anonymous reviewer for this idea.

${ }^{14}$ Internationalization has been measured in a variety of ways (e.g., Foreign Sales/Total Sales, Foreign Assets/Total Assets, Foreign Employees/ Total Employees, composition of TMT, number of subsidiaries, number of countries, number of regions, Degree of Internationalization index, entropy index, composite measures, Gravity Model). The measurement of internationalization has been an ongoing discussion in IB, albeit not specifically in relation to family firm internationalization. Therefore, we do not explore this generic operationalization issue in this study.

${ }^{15}$ Hennart et al. (2019) is an interesting example of an effective approach, since the authors use a gravity model to measure internationalization with theories that affect both international scale and scope similarly.

${ }^{16}$ The administrative heritage framework classifies MNEs into four general archetypes, each associated with the MNE's historical path as well as its dominant routines for international FSA transfer: (1) centralized exporters; (2) international projectors; (3) international coordinators; and (4) multicentered MNEs. Most large modern MNEs represent a combination of these archetypes.

Aldrich, H. E., \& Cliff, J. E. 2003. The pervasive effects of family on entrepreneurship: Toward a family embeddedness perspective. Journal of Business Venturing, 18(5): 573-596.

*Alessandri, T. M., Cerrato, D., \& Eddleston, K. A. 2018. The mixed gamble of internationalization in family and nonfamily firms: The moderating role of organizational slack. Global Strategy Journal, 8(1): 46-72.

*Almodóvar, P., Verbeke, A., \& Rodríguez-Ruiz, Ó. 2016. The internationalization of small and medium-sized family enterprises: The role of human asset quality. Journal of Leadership \& Organizational Studies, 23(2): 162-174.

*Amatori, F. 2016. The burden of the family company: Leopoldo Pirelli and his times. Business History, 58(7): 1008-1033.

Anderson, R. C., \& Reeb, D. M. 2003. Founding-family ownership and firm performance: Evidence from the S\&P 500. The Journal of Finance, 58(3): 1301-1328.

*Arregle, J.-L., Duran, P., Hitt, M. A., \& van Essen, M. 2017. Why is family firms' internationalization unique? A meta-analysis. Entrepreneurship Theory and Practice, 41(5): 801-831. 
*Arregle, J.-L., Hitt, M. A., \& Mari, I. 2019. A missing link in family firms' internationalization research: Family structures. Journal of International Business Studies, 50(5): 809-825.

Arregle, J.-L., Hitt, M. A., Sirmon, D. G., \& Very, P. 2007. The development of organizational social capital: Attributes of family firms. Journal of Management Studies, 44(1): 73-95.

Arregle, I.-L., Miller, T. L., Hitt, M. A., \& Beamish, P. W. 2016. How does regional institutional complexity affect MNE internationalization? Journal of International Business Studies, 47(6): 697-722.

*Arregle, J.-L., Naldi, L., Nordqvist, M., \& Hitt, M. A. 2012. Internationalization of family-controlled firms: A study of the effects of external involvement in governance. Entrepreneurship Theory and Practice, 36(6): 1115-1143.

$\mathrm{Au}, \mathrm{K}$. Y. 2000. Intra-cultural variation as another construct of international management: A study based on secondary data of 42 countries. Journal of International Management, 6(3): 217-238.

*Avrichir, I., Meneses, R., \& dos Santos, A. A. 2016. Do familymanaged and non-family-managed firms internationalize differently? Journal of Family Business Management, 6(3): 330-349.

*Banalieva, E., \& Eddleston, K. 2011. Home-region focus and performance of family firms: The role of family vs non-family leaders. Journal of International Business Studies, 42(8): 1060-1072.

Banfield, E. C. 1958. The moral basis of a backward society. Free Press.

*Bannò, M., \& Trento, S. 2016. International expansion of family firms: The moderating role of successors and external managers. International Journal of Globalisation and Small Business, 8(4): 292-315.

*Baronchelli, G., Bettinelli, C., Del Bosco, B., \& Loane, S. 2016. The impact of family involvement on the investments of Italian small-medium enterprises in psychically distant countries. International Business Review, 25(4): 960-970.

*Basly, S. 2007. The internationalization of family SME: An organizational learning and knowledge development perspective. Baltic Journal of Management, 2(2): 154-180.

Baù, M., Chirico, F., Pittino, D., Backman, M., \& Klaesson, J. 2019. Roots to grow: Family firms and local embeddedness in rural and urban contexts. Entrepreneurship Theory and Practice, 43(2): 360-385.

Bauweraerts, J., \& Vandernoot, J. 2019. An exploratory study on the influence of family CEOs on tax aggressiveness in private family firms: The moderating role of CEO gender and survival risk. Economics Bulletin, 39(1): 636-648.

Benito, G. R., Petersen, B., \& Welch, L. S. 2009. Towards more realistic conceptualizations of foreign operation modes. Journal of International Business Studies, 40(9): 1455-1470.

Berrone, P., Cruz, C., \& Gómez-Mejía, L. R. 2012. Socioemotional wealth in family firms: Theoretical dimensions, assessment approaches, and agenda for future research. Family Business Review, 25(3): 258-279.

Berrone, P., Duran, P., Gómez-Mejía, L., Heugens, P. P., Kostova, T., \& van Essen, M. 2020. Impact of informal institutions on the prevalence, strategy, and performance of family firms: A meta-analysis. Journal of International Business Studies.. https://doi.org/10.1057/s41267-020-00362-6.

Bird, M., \& Wennberg, K. 2014. Regional influences on the prevalence of family versus non-family start-ups. Journal of Business Venturing, 29(3): 421-436.

*Boellis, A., Mariotti, S., Minichilli, A., \& Piscitello, L. 2016. Family involvement and firms' establishment mode choice in foreign markets. Journal of International Business Studies, 47(8): 929-950.

*Boers, B. 2016. Go East! How family businesses choose markets and entry modes when internationalising. International Journal of Globalisation and Small Business, 8(4): 333-354.

Bourdieu, P. 1994. Raisons pratiques, Essais. Editions du Seuil.
Brouthers, K. D., \& Hennart, J.-F. 2007. Boundaries of the firm: Insights from international entry mode research. Journal of Management, 33(3): 395-425.

Buckley, P. J. 2016. Historical research approaches to the analysis of internationalisation. Management International Review, 56(6): 879-900.

Buckley, P. J., \& Casson, M. 1976. The future of the multinational enterprise. Macmillan.

Buckley, P. J., Doh, J. P., \& Benischke, M. H. 2017. Towards a renaissance in international business research? Big questions, grand challenges, and the future of IB scholarship. Journal of International Business Studies, 48(9): 1045-1064.

Buckley, P. J., \& Lessard, D. R. 2005. Regaining the edge for international business research. Journal of International Business Studies, 36(6): 595-599.

Burkart, M., Panunzi, F., \& Shleifer, A. 2003. Family firms. Journal of Finance, 58(5): 2167-2201.

*Calabrò, A., Mussolino, D., \& Huse, M. 2009. The role of board of directors in the internationalisation process of small and medium sized family businesses. International Journal of Globalisation and Small Business, 3(4): 393-411.

*Calabrò, A., Brogi, M., \& Torchia, M. 2016. What does really matter in the internationalization of small and medium-sized family businesses? Journal of Small Business Management, 54(2): 679-696.

*Calabrò, A., Torchia, M., Pukall, T. J., \& Mussolino, D. 2013. The influence of ownership structure and board strategic involvement on international sales: The moderating effect of family involvement. International Business Review, 22(3): 509-523.

Calori, R., Lubatkin, M., Very, P., \& Veiga, J. F. 1997. Modelling the origins of nationally-bound administrative heritages: A historical institutional analysis of French and British firms. Organization Science, 8(6): 681-696.

Cantwell, J. 1989. Technological innovation and multinational corporations. Blackwell.

*Carney, M., van Essen, M., Gedajlovic, E. R., \& Heugens, P. P. 2015. What do we know about private family firms? A meta-analytical Review. Entrepreneurship Theory and Practice, 39(3): 513-544.

${ }^{*}$ Carr, C., \& Bateman, S. 2009. International strategy configurations of the world's top family firms: Another factor affecting performance. Management International Review, 49(6): 733-758.

${ }^{*}$ Casillas, J. C., \& Acedo, F. J. 2005. Internationalisation of Spanish family SMEs: An analysis of family involvement. International Journal of Globalisation and Small Business, 1(2): 134-151.

*Casillas, J. C., Moreno, A. M., \& Acedo, F. J. 2010. Internationalization of family businesses: A theoretical model based on international entrepreneurship perspective. Global Management Journal, 2(2): 16-33.

Casillas, J. C., \& Moreno-Menéndez, A. M. 2017. International business \& family business: Potential dialogue between disciplines. European Journal of Family Business, 7(1-2): 25-40.

*Castagnoli, A. 2014. Across borders and beyond boundaries: How the Olivetti company became a multinational. Business History, 56(8): 1281-1311.

*Cesinger, B., Hughes, M., Mensching, H., Bouncken, R., Fredrich, V., \& Kraus, S. 2016. A socioemotional wealth perspective on how collaboration intensity, trust, and international market knowledge affect family firms' multinationality. Journal of World Business, 51(4): 586-599.

${ }^{*}$ Cheong, K. C., Lee, P. P., \& Lee, K. H. 2015. The internationalisation of family firms: Case histories of two Chinese overseas family firms. Business History, 57(6): 841-861.

Chirico, F., Gómez-Mejia, L. R., Hellerstedt, K., Withers, M., \& Nordqvist, M. 2020. To merge, sell, or liquidate? Socioemotional wealth, family control, and the choice of business exit. Journal of Management, 46(8): 1342-1379. 
Chirico, F., Ireland, R. D., \& Sirmon, D. G. 2011. Franchising and the family firm: Creating unique sources of advantage through "familiness." Entrepreneurship Theory and Practice, 35(3): 483-501.

Chrisman, J. J., Chua, J. H., \& Sharma, P. 2005. Trends and directions in the development of a strategic management theory of the family firm. Entrepreneurship Theory and Practice, 29(5): 555-576.

Chua, J. H., Chrisman, J. J., \& Sharma, P. 1999. Defining the family business by behavior. Entrepreneurship Theory and Practice, 23(4): 19-39.

*Claver, E., Rienda, L., \& Quer, D. 2008. Family firms' risk perception: Empirical evidence on the internationalization process. Journal of Small Business and Enterprise Development, 15(3): 457-471.

Coase, R. H. 1937. The nature of the firm. Economica, 4(16): 386-405.

*Colli, A., García-Canal, E., \& Guillén, M. F. 2013. Family character and international entrepreneurship: A historical comparison of Italian and Spanish 'new multinationals.' Business History, 55(1): 119-138.

${ }^{*}$ Cristiano, E. 2018. Internationalisation and corporate governance in family businesses: A case study. International Journal of Business Performance Management, 19(1): 75-86.

Cucculelli, M., \& Storai, D. 2015. Family firms and industrial districts: Evidence from the Italian manufacturing industry. Journal of Family Business Strategy, 6(4): 234-246.

*D'Angelo, A., Majocchi, A., \& Buck, T. 2016. External managers, family ownership and the scope of SME internationalization. Journal of World Business, 51(4): 534-547.

Davis, J. H., Schoorman, F. D., \& Donaldson, L. 1997. Toward a stewardship theory of management. Academy of Management Review, 22(1): 20-47.

Debicki, B. J., Kellermanns, F. W., Chrisman, J. J., Pearson, A. W., \& Spencer, B. A. 2016. Development of a socioemotional wealth importance (SEWi) scale for family firm research. Journal of Family Business Strategy, 7(1): 47-57.

*Debellis, F., De Massis, A., Petruzzelli, A. M., Frattini, F., \& Del Giudice, M. 2020a. Strategic agility and international joint ventures: The willingness ability paradox of family firms. Journal of International Management. https://doi.org/10.1016/ j.intman.2020.100739.

Debellis, F., Rondi, E., Plakoyiannaki, E., \& De Massis, A. 2020 b. Riding the waves of family firm internationalization: A systematic literature review, integrative framework, and research agenda. Journal of World Business. https://doi.org/ 10.1016/j.jwb.2020.101144.

De Massis, A., \& Foss, N. J. 2018. Advancing family business research: The promise of microfoundations. Family Business Review, 31(4): 386-396.

De Massis, A., Frattini, F., Majocchi, A., \& Piscitello, L. 2018. Family firms in the global economy: Toward a deeper understanding of internationalization determinants, processes, and outcomes. Global Strategy Journal, 8(1): 3-21.

Demsetz, H., \& Lehn, K. 1985. The structure of corporate ownership: Causes and consequences. Journal of Political Economy, 93(6): 1155-1177.

Dheer, R. J., Lenartowicz, T., \& Peterson, M. F. 2015. Mapping India's regional subcultures: Implications for international management. Journal of International Business Studies, 46(4): 443-467.

*Dick, M., Mitter, C., Feldbauer-Durstmüller, B., \& Pernsteiner, $\mathrm{H}$. 2017. The impact of finance and governance on the internationalisation modes of family firms. European Journal of International Management, 11(1): 42-64.

Donckels, R., \& Fröhlich, E. 1991. Are family businesses really different? European experiences from STRATOS. Family Business Review, 4(2): 149-160.

*Dou, J., Jacoby, G., Li, J., Su, Y., \& Wu, Z. 2019. Family involvement and family firm internationalization: The moderating effects of board experience and geographical distance.
Journal of International Financial Markets, Institutions and Money, 59: 250-261.

*Du, X., Zeng, Q., \& Chang, Y. 2018. To be philanthropic when being international: Evidence from Chinese family firms. Journal of Management \& Organization, 24(3): 424-449.

Dunford, M., \& Greco, L. 2007. Geographies of growth, decline and restructuring: The rise and fall (privatization) of the stateowned steel sector and the trajectories of steel localities in the Italian Mezzogiorno. European Urban and Regional Studies, 14(1): 27-53.

Dunning, J. H. 1993. Multinational enterprises and the global economy. Addison Wesley.

Dunning, J. H., \& Kundu, S. K. 1995. The internationalization of the hotel industry: Some new findings from a field study. Management International Review, 35(2): 101-133.

*Duran, P., Kostova, T., \& van Essen, M. 2017. Political ideologies and the internationalization of family-controlled firms. Journal of World Business, 52(4): 474-488.

Dyer, J. H., \& Singh, H. 1998. The relational view: Cooperative strategy and sources of interorganizational competitive advantage. Academy of Management Review, 23(4): 660-679.

Eddleston, K. A., Jaskiewicz, P., \& Wright, M. 2020. Family firms and internationalization in the Asia-Pacific: The need for multilevel perspectives. Asia Pacific Journal of Management, 37: 345-361.

*Eddleston, K. A., Sarathy, R., \& Banalieva, E. R. 2019. When a high-quality niche strategy is not enough to spur family-firm internationalization: The role of external and internal contexts. Journal of International Business Studies, 50: 783-808.

Faccio, M., Lang, L. H., \& Young, L. 2001. Dividends and expropriation. American Economic Review, 91(1): 54-78.

Family Firm Institute. (2017). Global Data Points. http://www.ffi. org/page/globaldatapoints. Retrieved from, November 27, 2017.

*Fang, H., Kotlar, J., Memili, E., Chrisman, J. J., \& De Massis, A. 2018. The pursuit of international opportunities in family firms: Generational differences and the role of knowledgebased resources. Global Strategy Journal, 8(1): 136-157.

Felin, T., Foss, N. J., \& Ployhart, R. E. 2015. The microfoundations movement in strategy and organization theory. The Academy of Management Annals, 9(1): 575-632.

*Fernández, Z., \& Nieto, M. J. 2005. Internationalization strategy of small and medium-sized family businesses: Some influential factors. Family Business Review, 18(1): 77-89.

*Fernández, Z., \& Nieto, M. 2006. Impact of ownership on the international involvement of SMEs. Journal of international Business Studies, 37(3): 340-351.

*Fernández-Moya, M. 2010. A family-owned publishing multinational: The Salvat company (1869-1988). Business History, 52(3): 453-470.

*Filatotchev, I., Strange, R., Piesse, J., \& Lien, Y. C. 2007. FDI by firms from newly industrialised economies in emerging markets: Corporate governance, entry mode and location. Journal of International Business Studies, 38(4): 556-572.

Fischer, R., \& Schwartz, S. H. 2011. Whence difference in value priorities? Individual, cultural, or artifactual sources. Journal of Cross-cultural Psychology, 42(7): 1127-1144.

Forsgren, M. 2017. Theories of the multinational firm: A multidimensional creature in the global economy. Edward Elgar Publishing.

*Gallo, M. A., \& Pont, C. G. 1996. Important factors in family business internationalization. Family Business Review, 9(1): 45-59.

Gallo, M. A., \& Sveen, J. 1991. Internationalizing the family business: Facilitating and restraining factors. Family Business Review, 4(2): 181-190.

*Geppert, M., Dörrenbächer, C., Gammelgaard, J., \& Taplin, I. 2013. Managerial risk-taking in international acquisitions in the brewery industry: Institutional and ownership influences compared. British Journal of Management, 24(3): 316-332. 
Ghemawat, P. 2003a. Semiglobalization and international business strategy. Journal of International Business Studies, 34(2): 138-152.

Ghemawat, P. 2003b. The forgotten strategy. Harvard Business Review, 81(11): 76-84.

Gómez-Mejía, L. R., Campbell, J. T., Martin, G., Hoskisson, R. E., Makri, M., \& Sirmon, D. G. 2014. Socioemotional wealth as a mixed gamble: Revisiting family firm $R \& D$ investments with the behavioral agency model. Entrepreneurship Theory and Practice, 38(6): 1351-1374.

Gómez-Mejía, L. R., Haynes, K. T., Núñez-Nickel, M., Jacobson, K. J., \& Moyano-Fuentes, J. 2007. Socioemotional wealth and business risks in family-controlled firms: Evidence from Spanish olive oil mills. Administrative Science Quarterly, 52(1): 106-137.

*Gómez-Mejía, L. R., Makri, M., \& Larraza Kintana, M. L. 2010. Diversification decisions in family-controlled firms. Journal of Management Studies, 47(2): 223-252.

*Graves, C., \& Shan, Y. G. 2014. An empirical analysis of the effect of internationalization on the performance of unlisted family and nonfamily firms in Australia. Family Business Review, 27(2): 142-160.

*Graves, C., \& Thomas, J. 2008. Determinants of the internationalization pathways of family firms: An examination of family influence. Family Business Review, 21(2): 151-167.

Greenwood, R., Díaz, A. M., Li, S. X., \& Lorente, J. C. 2010. The multiplicity of institutional logics and the heterogeneity of organizational responses. Organization science, 21(2): 521-539.

*Harlaftis, G., \& Theotokas, J. 2004. European family firms in international business: British and Greek tramp-shipping firms. Business History, 46(2): 219-255.

Hauck, J., Suess-Reyes, J., Beck, S., Prügl, R., \& Frank, H. 2016. Measuring socioemotional wealth in family-owned and-managed firms: A validation and short form of the FIBER Scale. Journal of Family Business Strategy, 7(3): 133-148.

*Heileman, M. D., \& Pett, T. L. 2018. Should family firms internationalize? Evidence from the Survey of Business Owners. Journal of Small Business Strategy, 28(1): 1-13.

Hennart, J.-F. 1982. A theory of multinational enterprise. University of Michigan Press.

Hennart, J.-F. 2007. The theoretical rationale for a multinationality-performance relationship. Management International Review, 47(3): 307-317.

Hennart, J.-F. 2012. Emerging market multinationals and the theory of the multinational enterprise. Global Strategy Journal, 2(3): 168-187.

*Hennart, J.-F., Majocchi, A., \& Forlani, E. 2019. The myth of the stay-at-home family firm: How family-managed SMEs can overcome their internationalization limitations. Journal of International Business Studies, 50(5): 758-782.

*Hernández-Perlines, F., Moreno-García, J., \& Yañez-Araque, B. 2016. The mediating role of competitive strategy in international entrepreneurial orientation. Journal of Business Research, 69(11): 5383-5389.

*Hernández-Perlines, F., \& Xu, W. 2018. Conditional mediation of absorptive capacity and environment in international entrepreneurial orientation of family businesses. Frontiers in Psychology, 9(102): 1-14.

*Herrera-Echeverri, H., Geleilate, J. G., Gaitan-Riaño, S., Haar, J., \& Soto-Echeverry, N. 2016. Export behavior and board independence in Colombian family firms: The reverse causality relationship. Journal of Business Research, 69(6): 2018-2029.

Heugens, P. P., van Essen, M., \& van Oosterhout, J. H. 2009. Meta-analyzing ownership concentration and firm performance in Asia: Towards a more fine-grained understanding. Asia Pacific Journal of Management, 26(3): 481-512.

Hitt, M. A., Bierman, L., Uhlenbruck, K., \& Shimizu, K. 2006. The importance of resources in the internationalization of professional service firms: The good, the bad and the ugly. Academy of Management Journal, 49(6): 1137-1157.
*Holt, D. T. 2012. Strategic Decisions within Family Firms: Understanding the Controlling Family's Receptivity to Internationalization. Entrepreneurship Theory and Practice, 36(6): 1145-1151.

Hoskisson, R. E., Chirico, F., Zyung, J., \& Gambeta, E. 2017. Managerial risk taking: A multitheoretical review and future research agenda. Journal of Management, 43(1): 137-169.

*Hsu, C. H., Kao, M. S., \& Lee, L. M. 2016. The value of internationalization for emerging market firms - Family versus non-family firms. Economics Bulletin, 36(2): 1214-1222.

*Huesca-Dorantes, J. L., Michailova, S., \& Stringer, C. 2018. Aztec multilatinas: Characteristics and strategies of Mexican multinationals. Review of International Business and Strategy, 28(1): 2-18.

Jackson, G., \& Deeg, R. 2008. Comparing capitalisms: Understanding institutional diversity and its implications for international business. Journal of International Business Studies, 39(4): 540-561.

James, H. S. 1999. Owner as manager, extended horizons and the family firm. International Journal of the Economics of Business, 6: 41-55.

Janis, I. 1982. Groupthink: Psychological studies of policy decisions and fiascoes. Houghton Mifflin.

Jaskiewicz, P., Combs, J. G., \& Rau, S. B. 2015. Entrepreneurial legacy: Toward a theory of how some family firms nurture transgenerational entrepreneurship. Journal of Business Venturing, 30(1): 29-49.

Jaskiewicz, P., Combs, J., Shanine, K., \& Kacmar, M. 2017. Introducing the family: A review of family science with implications for management research. Academy of Management Annals, 11(1): 309-341.

Jaskiewicz, P., \& Dyer, W. G. 2017. Addressing the elephant in the room: Disentangling family heterogeneity to advance family business research. Family Business Review, 30(2): 111-118.

liang, D. S., Kellermanns, F. W., Munyon, T. P., \& Morris, M. L. 2018. More than meets the eye: A review and future directions for the social psychology of socioemotional wealth. Family Business Review, 31(1): 125-157.

* Jimenez, A., Majocchi, A., \& Della Piana, B. 2019. Not all family firms are equal: The moderating effect of family involvement on the political risk exposure of the foreign direct investment portfolio. Preliminary evidence from Spanish multinational enterprises. Thunderbird International Business Review, 61(2): 309-323.

Johanson, J., \& Vahlne, J. E. 1977. Internationalization process of firm-A model of knowledge development and increasing foreign market commitments. Journal of International Business Studies, 8(1): 23-32.

Johanson, J., \& Vahlne, J. E. 2009. The Uppsala internationalization process model revisited: From liability of foreignness to liability of outsidership. Journal of International Business Studies, 40(9): 1411-1431.

Kahneman, D. 2003. Maps of bounded rationality: Psychology for behavioral economics. American Economic Review, 93(5): 1449-1475.

*Kano, L., Ciravegna, L., \& Rattalino, F. 2021. The family as a platform for FSA development: Enriching new internalization theory with insights from family firm research. Journal of international Business Studies, 52(1): 148-160.

*Kano, L., \& Verbeke, A. 2018. Family firm internationalization: Heritage assets and the impact of bifurcation bias. Global Strategy Journal, 8(1): 158-183.

Kano, L., \& Verbeke, A. 2019. Theories of the multinational firm: A microfoundational perspective. Global Strategy Journal, 9(1): 117-147.

*Kao, M. S., \& Kuo, A. 2017. The effect of uncertainty on FDI entry mode decisions: The influence of family ownership and involvement in the board of directors. Journal of Family Business Strategy, 8(4): 224-236. 
*Kao, M. S., Kuo, A., \& Chang, Y. C. 2013. How family control influences FDI entry mode choice. Journal of Management \& Organization, 19(4): 367-385.

Kellermanns, F. W., \& Eddleston, K. A. 2004. Feuding families: When conflict does a family firm good. Entrepreneurship Theory and Practice, 28(3): 209-228.

*Kim, H., Hoskisson, R. E., \& Zyung, J. D. 2019. Socioemotional favoritism: Evidence from foreign divestitures in family multinationals. Organization Studies, 40(6): 917-940.

Kogut, B., \& Zander, U. 1992. Knowledge of the firm, combinative capabilities, and the replication of technology. Organization Science, 3(3): 383-397.

*Kontinen, T., \& Ojala, A. 2010. Internationalization pathways of family SMEs: Psychic distance as a focal point. Journal of Small Business and Enterprise Development, 17(3): 437-454.

*Kontinen, T., \& Ojala, A. 2011. International opportunity recognition among small and medium-sized family firms. Journal of Small Business Management, 49(3): 490-514.

*Kontinen, T., \& Ojala, A. 2012. Social capital in the international operations of family SMEs. Journal of Small Business and Enterprise Development, 19(1): 39-55.

Kotlar, J., \& De Massis, A. 2013. Goal setting in family firms: Goal diversity, social interactions, and collective commitment to family-centered goals. Entrepreneurship Theory and Practice, 37(6): 1263-1288.

*Kraus, S., Mensching, H., Calabrò, A., Cheng, C. F., \& Filser, M. 2016. Family firm internationalization: A configurational approach. Journal of Business Research, 69(11): 5473-5478.

Kuiken, A. (2019). Exploring the internationalization of small and medium-sized enterprises as a discontinuous process. Unpublished Ph.D. Dissertation, Jönköping International Business School, Jönköping University, Jönköping, Sweden.

*Kuo, A., Kao, M. S., Chang, Y. C., \& Chiu, C. F. 2012. The influence of international experience on entry mode choice: Difference between family and non-family firms. European Management Journal, 30(3): 248-263.

Lahiri, S., Mukherjee, D., \& Peng, M. W. 2020. Behind the internationalization of family SMEs: A strategy tripod synthesis. Global Strategy Journal, 10(4): 813-838.

Lazonick, W., \& O'Sullivan, M. 2000. Maximizing shareholder value: A new ideology for corporate governance. Economy and Society, 29: 13-35.

Le Breton-Miller, I., Miller, D., \& Lester, R. H. 2011. Stewardship or agency? A social embeddedness reconciliation of conduct and performance in public family businesses. Organization science, 22(3): 704-721.

*Lehrer, M., \& Celo, S. 2017. Boundary-spanning and boundary-buffering in global markets: A German perspective on the internationalization of family firms. Review of International Business and Strategy, 27(2): 161-179.

*Lien, Y. C., \& Filatotchev, I. 2015. Ownership characteristics as determinants of FDI location decisions in emerging economies. Journal of World Business, 50(4): 637-650.

*Lin, W. T. 2012. Family ownership and internationalization processes: Internationalization pace, internationalization scope, and internationalization rhythm. European Management Journal, 30(1): 47-56.

*Lu, J. W., Liang, X., Shan, M., \& Liang, X. 2015. Internationalization and performance of Chinese family firms: The moderating role of corporate governance. Management and Organization Review, 11(4): 645-678.

*Luo, X., Chung, C. N., \& Sobczak, M. 2009. How do corporate governance model differences affect foreign direct investment in emerging economies? Journal of International Business Studies, 40(3): 444-467.

Luo, Y., \& Tung, R. L. 2018. A general theory of springboard MNEs. Journal of International Business Studies, 49(2): 129-152.

Maitland, E., \& Sammartino, A. 2015. Managerial cognition and internationalization. Journal of International Business Studies, 46(7): 733-760.
*Majocchi, A., D'Angelo, A., Forlani, E., \& Buck, T. 2018. Bifurcation bias and exporting: Can foreign work experience be an answer? Insight from European family SMEs. Journal of World Business, 53(2): 237-247.

*Majocchi, A., \& Strange, R. 2012. International diversification: The impact of ownership structure, the market for corporate control and board independence. Management International Review, 52(6): 879-900.

*Marinova, S., \& Marinov, M. 2017. Inducing the internationalisation of family manufacturing firms from a transition context. European Business Review, 29(2): 181-204.

McGrath, R. G. 1999. Falling forward: Real options reasoning and entrepreneurial failure. Academy of Management Review, 24(1): 13-30.

*Mensching, H., Calabrò, A., Eggers, F., \& Kraus, S. 2016. Internationalisation of family and non-family firms: A conjoint experiment among CEOs. European Journal of International Management, 10(5): 581-604.

Metsola, J., Leppäaho, T., Paavilainen-Mäntymäki, E., \& Plakoyiannaki, E. 2020. Process in family business internationalisation: The state of the art and ways forward. International Business Review, 29(2): 101665.

Meyer, K. E., \& Peng, M. W. 2016. Theoretical foundations of emerging economy business research. Journal of International Business Studies, 47(1): 3-22.

Miller, D., \& Chen, M. J. 1996. The simplicity of competitive repertoires: An empirical analysis. Strategic Management Journal, 17(6): 419-439.

Miller, D., \& Le Breton-Miller, I. 2005. Managing for the long run: Lessons in competitive advantage from great family businesses. Harvard Business Press.

*Minetti, R., Murro, P., \& Zhu, S. C. 2015. Family firms, corporate governance and export. Economica, 82: 1177-1216.

*Mitter, C., Duller, C., Feldbauer-Durstmüller, B., \& Kraus, S. 2014. Internationalization of family firms: The effect of ownership and governance. Review of Managerial Science, 8(1): 1-28.

*Monreal-Pérez, J., \& Sánchez-Marín, G. 2017. Does transitioning from family to non-family controlled firm influence internationalization? Journal of Small Business and Enterprise Development, 24(4): 775-792.

Morck, R., Wolfenzon, D., \& Yeung, B. 2005. Corporate governance, economic entrenchment, and growth. Journal of Economic Literature, 43(3): 655-720.

Mustakallio, M., Autio, E., \& Zahra, S. A. 2002. Relational and contractual governance in family firms: Effects on strategic decision making. Family Business Review, 15: 205-222.

Naldi, L., Cennamo, C., Corbetta, G., \& Gómez-Mejía, L. 2013. Preserving socioemotional wealth in family firms: Asset or liability? The moderating role of business context. Entrepreneurship Theory and Practice, 37(6): 1341-1360.

Neckebrouck, J., Schulze, W., \& Zellweger, T. 2018. Are family firms good employers? Academy of Management Journal, 61(2): 553-585.

North, D. C. 1990. A transaction cost theory of politics. Journal of Theoretical Politics, 2(4): 355-367.

*Okoroafo, S. C. 1999. Internationalization of family businesses: Evidence from Northwest Ohio, USA. Family Business Review, 12(2): 147-158.

*Okoroafo, S. C., \& Perryy, M. 2010. Generational perspectives of the export behavior of family businesses. International Journal of Economics and Finance, 2(3): 15-24.

Olson, D. H. 1986. Circumplex model VII: Validation studies and FACES III. Family Process, 25: 337-351.

Olson, D. H. 2000. Circumplex model of marital and family systems. Journal of Family Therapy, 22(2): 144-167.

*Pérez, P. F., \& Puig, N. 2009. Global lobbies for a global economy: The creation of the Spanish Institute of Family Firms in international perspective. Business History, 51(5): 712-733.

Peterson, M. F., Søndergaard, M., \& Kara, A. 2018. Traversing cultural boundaries in IB: The complex relationships between 
explicit country and implicit cultural group boundaries at multiple levels. Journal of International Business Studies, 49(8): 1081-1099.

*Pongelli, C., Calabrò, A., \& Basco, R. 2019. Family firms' international make-or-buy decisions: Captive offshoring, offshore outsourcing, and the role of home region focus. Journal of Business Research, 103: 596-606.

*Pongelli, C., Caroli, M. G., \& Cucculelli, M. 2016. Family business going abroad: The effect of family ownership on foreign market entry mode decisions. Small Business Economics, 47(3): 787-801.

Prahalad, C. K., \& Doz, Y. L. 1987. The multinational mission: Balancing global integration with local responsiveness. Free Press.

*Procher, V. D., Urbig, D., \& Volkmann, C. 2013. Time to BRIC it? Internationalization of European family firms in Europe, North America and the BRIC countries. Applied Economics Letters, 20(16): 1466-1471.

*Puig, N., \& Pérez, P. F. 2009. A silent revolution: The internationalisation of large Spanish family firms. Business History, 51(3): 462-483.

*Pukall, T. J., \& Calabrò, A. 2014. The internationalization of family firms: A critical review and integrative model. Family Business Review, 27(2): 103-125.

*Purkayastha, S., Manolova, T. S., \& Edelman, L. F. 2018. Business group effects on the R\&D intensity-internationalization relationship: Empirical evidence from India. Journal of World Business, 53(2): 104-117.

*Ramón-Llorens, M. C., García-Meca, E., \& Duréndez, A. 2017. Influence of CEO characteristics in family firms internationalization. International Business Review, 26(4): 786-799.

Ramos, H. M., Man, T. W. Y., Mustafa, M., \& Ng, Z. Z. 2014. Psychological ownership in small family firms: Family and nonfamily employees' work attitudes and behaviours. Journal of Family Business Strategy, 5(3): 300-311.

*Ratten, V., \& Tajeddini, K. 2017. Innovativeness in family firms: An internationalization approach. Review of International Business and Strategy, 27(2): 217-230.

*Ray, S., Mondal, A., \& Ramachandran, K. 2018. How does family involvement affect a firm's internationalization? An investigation of Indian family firms. Global Strategy Journal, 8(1): 73-105.

Redding, G. 2005. The thick description and comparison of societal systems of capitalism. Journal of International Business Studies, 36(2): 123-155.

*Reuber, A. R. 2016. An assemblage-theoretic perspective on the internationalization processes of family firms. Entrepreneurship Theory and Practice, 40(6): 1269-1286.

*Rienda, L., Claver, E., Quer, D., \& Andreu, R. 2019. Family businesses from emerging markets and choice of entry mode abroad: Insights from Indian firms. Asian Business \& Management, 18(1): 6-30.

Rugman, A. M. 1981. Inside the multinationals: The economics of internal markets. Columbia University Press.

Rugman, A. M., \& Verbeke, A. 2004. A perspective on regional and global strategies of multinational enterprises. Journal of International Business Studies, 35(1): 3-18.

Salvato, C., Chirico, F., Melin, L., \& Seidl, D. 2019. Coupling family business research with organization studies: Interpretations, issues and insights. Organization Studies, 40(6): 775-791.

Salvato, C., Chirico, F., \& Sharma, P. 2010. A farewell to the business: Championing exit and continuity in entrepreneurial family firms. Entrepreneurship \& Regional Development, 22(3-4): 321-348.

*Santulli, R., Torchia, M., Calabrò, A., \& Gallucci, C. 2019. Family ownership concentration and firm internationalization: Integrating principal-principal and socioemotional wealth perspectives. Journal of International Entrepreneurship, 17(2): 220-248.
Schulze, W. S., Lubatkin, M. H., \& Dino, R. N. 2003. Toward a theory of agency and altruism in family firms. Journal of Business Venturing, 18(4): 473-490.

Sciascia, S., Mazzola, P., \& Chirico, F. 2013. Generational involvement in the top management team of family firms: Exploring nonlinear effects on entrepreneurial orientation. Entrepreneurship Theory and Practice, 37(1): 69-85.

Shamseer, L., Moher, D., Clarke, M., Ghersi, D., Liberati, A., Petticrew, M., Shekelle, P., Stewart, L., \& PRISMA-P Group 2014. Preferred reporting items for systematic review and meta-analysis protocols (PRISMA-P) 2015: Elaboration and explanation. British Management Journal, 349: g7647.

Schulze, W. S., \& Kellermanns, F. W. 2015. Reifying socioemotional wealth. Entrepreneurship: Theory and Practice, 39(3): 447.

Schulze, W. S., Lubatkin, M. H., Dino, R. N., \& Buchholtz, A. K. 2001. Agency relationships in family firms: Theory and evidence. Organization Science, 12: 99-116.

*Scholes, L., Mustafa, M., \& Chen, S. 2016. Internationalization of small family firms: The influence of family from a socioemotional wealth perspective. Thunderbird International Business Review, 58(2): 131-146.

*Sciascia, S., Mazzola, P., Astrachan, J. H., \& Pieper, T. M. 2012. The role of family ownership in international entrepreneurship: Exploring nonlinear effects. Small Business Economics, 38(1): 15-31.

*Sestu, M. C., \& Majocchi, A. 2020. Family firms and the choice between wholly owned subsidiaries and joint ventures: A Transaction Costs perspective. Entrepreneurship Theory and Practice, 44(2): 211-232.

*Shapiro, D. M., Gedajlovic, E., \& Erdener, C. 2003. The Chinese family firm as a multinational enterprise. The International Journal of Organizational Analysis, 11(2): 105-122.

*Singh, D. A., \& Gaur, A. S. 2013. Governance structure, innovation and internationalization: Evidence from India. Journal of International Management, 19(3): 300-309.

Singla, C., George, R., \& Veliyath, R. 2017. Ownership structure and internationalization of Indian firms. Journal of Business Research, 81: 130-143.

*Singla, C., Veliyath, R., \& George, R. 2014. Family firms and internationalization-governance relationships: Evidence of secondary agency issues. Strategic Management Journal, 35: 606-616.

*Sirmon, D. G., Arregle, J. L., Hitt, M. A., \& Webb, J. W. 2008. The role of family influence in firms' strategic responses to threat of imitation. Entrepreneurship: Theory \& Practice, 32: 979-998.

Sirmon, D. G., \& Hitt, M. A. 2003. Managing resources: Linking unique resources, management, and wealth creation in family firms. Entrepreneurship: Theory \& Practice, 27: 339-358.

Soleimanof, S., Rutherford, M. W., \& Webb, J. W. 2018. The intersection of family firms and institutional contexts: A review and agenda for future research. Family Business Review, 31(1): 32-53.

*Stadler, C., Mayer, M. C., Hautz, J., \& Matzler, K. 2018. International and product diversification: Which strategy suits family managers? Global Strategy Journal, 8(1): 184-207.

*Stieg, P., Cesinger, B., Apfelthaler, G., Kraus, S., \& Cheng, C. F. 2018. Antecedents of successful internationalization in family and non-family firms: How knowledge resources and collaboration intensity shape international performance. Journal of Small Business Strategy, 28(1): 14-27.

Stieg, P., Hiebl, M. R., Kraus, S., Schüssler, F., \& Sattler, S. 2017. Born-again globals: Generational change and family business internationalisation. European Journal of International Management, 11(5): 581-605.

*Strange, R., Filatotchev, I., Lien, Y. C., \& Piesse, J. 2009. Insider control and the FDI location decision. Management International Review, 49(4): 433-454.

*Suman, S. 2017. Leveraging corporate theory to examine the internationalisation process of family businesses. Journal for 
International Business and Entrepreneurship Development, 10(4): 362-378.

*Sundaramurthy, C., \& Dean, M. A. 2008. Family businesses' openness to external influence and international sales: An empirical examination. Multinational Business Review, 16(2): 89-106.

The Economist. (2015, April 15). To have and to hold. https:// www.economist.com/special-report/2015/04/16/to-haveand-to-hold. Retrieved from, January 10, 2020.

Thornton, P. H. 2004. Markets from culture: Institutional logics and organizational decisions in higher education publishing. Stanford University Press.

Todd, E. 1985. The explanation of ideology, family structures and social systems. Basil Blackwell.

Todd, E. 2011. L'origine des systèmes familiaux. Tome 1: L'Eurasie. Paris: Gallimard.

Tranfield, D., Denyer, D., \& Smart, P. 2003. Towards a methodology for developing evidence-informed management knowledge by means of systematic review. British Journal of Management, 14(3): 207-222.

Tsang, E. W. K. 2006. Behavioral assumptions and theory development: The case of transaction cost economics. Strategic Management Journal, 27(11): 999-1011.

*Tsang, E. W. K. 2020. Family firms and internationalization: An organizational learning perspective. Asia Pacific Journal of Management, 37: 205-225.

*Tsao, S. M., \& Lien, W. H. 2013. Family management and internationalization: The impact on firm performance and innovation. Management International Review, 53(2): 189-213.

Tunberg, M. 2014. Approaching rural firm growth: A literature review. Journal of Enterprising Communities, 8(4): 261-286.

Tversky, A., \& Kahneman, D. 1974. Judgment under uncertainty: Heuristics and biases. Science, 185(4157): 1124-1131.

Vahlne, J. E., \& Johanson, J. 2017. From internationalization to evolution: The Uppsala model at 40 years. Journal of International Business Studies, 48(9): 1087-1102.

*van Essen, M., Carney, M., Gedajlovic, E. R., \& Heugens, P. P. 2015. How does family control influence firm strategy and performance? A meta-analysis of US publicly listed firms. Corporate Governance: An International Review, 23(1): 3-24.

Verbeke, A. 2013. International business strategy. Cambridge University Press.

Verbeke, A., \& Brugman, P. 2009. Triple-testing the quality of multinationality-performance research: An internalization theory perspective. International Business Review, 18(3): 265-275.

Verbeke, A., \& Forootan, M. Z. 2012. How good are multinationality-performance (M-P) empirical studies? Global Strategy Journal, 2(4): 332-344.

Verbeke, A., \& Kano, L. 2012. The transaction cost economics theory of the family firm: Family-based human asset specificity and the bifurcation bias. Entrepreneurship Theory and Practice, 36(6): 1183-1205.

Verbeke, A., \& Kano, L. 2015. The new internalization theory and multinational enterprises from emerging economies: A business history perspective. Business History Review, 89(3): 415-445.

Verbeke, A., \& Kano, L. 2016. An internalization theory perspective on the global and regional strategies of multinational enterprises. Journal of World Business, 51(1): 83-92.

*Verbeke, A., Yuan, W., \& Kano, L. 2020. A values-based analysis of bifurcation bias and its impact on family firm internationalization. Asia Pacific Journal of Management, 37(2): 449-477.

Wan, W. P., Hoskisson, R. E., Short, J. C., \& Yiu, D. W. 2011. Resource-based theory and corporate diversification: Accomplishments and opportunities. Journal of Management, 37(5): 1335-1368.

*Wei, Y. C., \& Tsao, C. W. 2019. Family influences in the internationalization of the top 1,000 Taiwanese enterprises. Chinese Management Studies, 13(1): 128-145.
Whitley, R. D. 1992. European business systems, firms, and markets in their national contexts. Sage.

Williamson, O. E. 1975. Markets and hierarchies: Analysis and antitrust implications: $A$ study in the economics of internal organizations. Free Press, Macmillan.

Williamson, O. E. 1981. The economics of organization: The transaction cost approach. The American Journal of Sociology, 87(3): 548-577.

Williamson, O. E. 1996. The mechanisms of governance. Oxford University Press.

*Xu, K., Hitt, M. A., \& Dai, L. 2020a. International diversification of family-dominant firms: Integrating socioemotional wealth and behavioral theory of the firm. Journal of World Business, 55(3): 101071

*Xu, K., Hitt, M. A., \& Miller, S. R. 2020b. The ownership structure contingency in the sequential international entry mode decision process: Family owners and institutional investors in family-dominant versus family-influenced firms. Journal of International Business Studies, 51(2): 151-171.

*Yamanoi, J., \& Asaba, S. 2018. The impact of family ownership on establishment and ownership modes in foreign direct investment: The moderating role of corruption in host countries. Global Strategy Journal, 8(1): 106-135.

*Yang, X., Li, J., Stanley, L. J., Kellermanns, F. W., \& Li, X. 2018. How family firm characteristics affect internationalization of Chinese family SMEs. Asia Pacific Journal of Management, 37(2): 417-448.

*Zaefarian, R., Eng, T. Y., \& Tasavori, M. 2016. An exploratory study of international opportunity identification among family firms. International Business Review, 25(1): 333-345.

Zaheer, S. 1995. Overcoming the liability of foreignness. Academy of Management Journal, 38(2): 341-363.

*Zahra, S. 2003. International expansion of US manufacturing family businesses: The effect of ownership and involvement. Journal of Business Venturing, 18(4): 495-512.

Zellweger, T. M., \& Astrachan, J. H. 2008. On the emotional value of owning a firm. Family Business Review, 21(4): 347-363.

\section{ABOUT THE AUTHORS}

Jean-Luc Arregle is a Professor of Strategy at EM Lyon business school, France. His research interests include MNEs' international strategies, the roles of institutions, semiglobalization, and family firms.

Francesco Chirico is a Professor of Strategy and Family Business at Macquarie Business School and Jonkoping International Business School. His research focuses on the intersection of strategy and entrepreneurship with a special focus on resource management processes, and acquisition and divestiture strategies that affect the realization of competitive advantage, innovation, and financial and nonfinancial wealth in family firms.

Liena Kano is an Associate Professor of Strategy and Global Management at the Haskayne School of Business, University of Calgary, Canada. Her research intersects strategic management, international business, and entrepreneurship, with a particular focus on novel applications of 
internalization theory, and on microfoundations that underlie complex international governance decisions.

Sumit K. Kundu is the James K. Batten Eminent Scholar Chair in International Business in the College of Business at Florida International University. His research interests are in theory of multinational enterprise, international entrepreneurship, emerging market multinationals, service multinationals, and global strategic management.

Antonio Majocchi is a Professor of International Business at the Luiss Guido Carli University in Rome (Italy). His research focuses on the theory of MNCs, firm internationalization strategies, and the impact of corporate governance on these strategies. $\mathrm{He}$ has held visiting positions at Northeastern University, the University of Valencia, and Fribourg University.

William S. Schulze (Ph.D., U of Colorado) is a David Eccles Professor in the Entrepreneurship and
Strategy Department at the University of Utah. His research focuses on the intersection of strategic management and entrepreneurship, with a focus on wealth creation, learning, and the governance of entrepreneurial and family firms.

Open Access This article is licensed under a Creative Commons Attribution 4.0 International License, which permits use, sharing, adaptation, distribution and reproduction in any medium or format, as long as you give appropriate credit to the original author(s) and the source, provide a link to the Creative Commons licence, and indicate if changes were made. The images or other third party material in this article are included in the article's Creative Commons licence, unless indicated otherwise in a credit line to the material. If material is not included in the article's Creative Commons licence and your intended use is not permitted by statutory regulation or exceeds the permitted use, you will need to obtain permission directly from the copyright holder. To view a copy of this licence, visit http://creativecommons.org/licenses/by/4.0/.

Publisher's Note Springer Nature remains neutral with regard to jurisdictional claims in published maps and institutional affiliations.

Accepted by Ilan Vertinsky, Area Editor, 4 March 2021. This article has been with the authors for three revisions. 